\title{
Guidelines and limitations for the design of high-efficiency InGaN single-junction solar cells
}

\author{
Chloe A. M. Fabien ${ }^{\mathrm{a}}$, W. Alan Doolittle ${ }^{\mathrm{a} *}$ \\ ${ }^{a}$ School of Electrical and Computer Engineering, Georgia Institute of Technology, Atlanta, GA \\ 30332, USA. \\ * Corresponding author at: Georgia Institute of Technology, Atlanta, GA 30332, USA. \\ Tel.: +1 4048949884 \\ E-mail address: alan.doolittle@ece.gatech.edu (W. A. Doolittle)
}

\section{ASTRACT}

Indium gallium nitride ( $\mathrm{InGaN}$ ) alloys offer great potential for high-efficiency photovoltaics, yet theoretical promise has not been experimentally demonstrated. Several major challenges remain including polarization effects, suitable p-type doping, improved surface passivation, and growth of thick, high-quality InGaN layers. In this paper, we present numerical simulations of InGaN p-i-n single-junction solar cells to provide guidelines for performance improvement through optimization of device structures given achievable material characteristics. The performance of both $\mathrm{InGaN} / \mathrm{GaN}$ heterojunction devices that are presently achievable and InGaN homojunction solar cells that should be feasible in the future are investigated through the calculation of characteristic parameters: short-circuit current density, open-circuit voltage, and conversion efficiency. These simulations study the effect of indium content, thickness, and background doping of the unintentionally-doped InGaN absorbing layer on the performance of both InGaN solar-cell designs. While the maximum efficiency of a $\mathrm{p}-\mathrm{i}-\mathrm{n}$ InGaN/GaN heterojunction solar cell with low indium composition is $11.3 \%$, the conversion efficiency of heterojunction devices with high indium composition needed for longer wavelength absorption drastically reduces because of polarization effects. Above an indium composition of $45 \%$, the modeled heterojunction devices do not operate as solar cells. Using presently achievable values of minority carrier lifetime and surface recombination velocity, the maximum efficiency of InGaN single-homojunction solar cells with optimized parameters is $\sim 17 \%$, which is significantly smaller than the theoretical maximum energy-conversion efficiency for singlejunction cells. 


\section{INTRODUCTION}

As silicon solar cells are now approaching their theoretical maximum efficiency, alternative materials for high-efficiency photovoltaics need to be investigated. A promising candidate for high-efficiency solar cells is indium gallium nitride ( $\operatorname{InGaN})$ alloys [1, 2]. The major advantage of the InGaN material is tunable band gaps over the alloy composition ranging from 0.65 to 3.42 $\mathrm{eV}$ [3] and thus, covering nearly the entire solar spectrum. Because of this wide range of band gaps, InGaN alloys show considerable promise for high-efficiency multijunction solar cells. Several InGaN subcells with adjusted indium content can be stacked to form a full-spectrumresponse solar cell based on a single-material system [4]. Another multijunction design consists of an InGaN/Si tandem solar cell. Such a device would benefit from mature and low-cost silicon technology. Hsu et al. [5] proposed a two-junction solar cell comprised of an $\operatorname{In}_{0.46} \mathrm{Ga}_{0.54} \mathrm{~N}$ subcell $(1.8 \mathrm{eV})$ on top of an $\mathrm{Si}$ subcell $(1.1 \mathrm{eV})$. These band gaps are close to the most efficient combination predicted for two-junction solar cells [6]. In addition, the conduction band of $\operatorname{In}_{0.46} \mathrm{Ga}_{0.54} \mathrm{~N}$ is aligned with the valence band of $\mathrm{Si}$ so that the $\mathrm{p}-\mathrm{Si} / \mathrm{n}-\operatorname{In}_{0.46} \mathrm{Ga}_{0.54} \mathrm{~N}$ interface forms a low-resistance contact for the series connection of the two subcells [5]. Moreover, InGaN alloys display high absorption coefficients $\left(\sim 10^{5} \mathrm{~cm}^{-1}\right)[7,8]$. Thus, only a few hundred nanometers of InGaN material are required to absorb most of the incident light, thereby rendering moderately expensive indium more cost effective. In contrast, several hundred microns of silicon are needed to absorb a large fraction of incident light [9]. Other suitable photovoltaic properties include a direct band gap over the entire alloy composition range, high carrier mobility [10], high drift velocity, and superior radiation resistance for space-based photovoltaic applications [11].

Despite these suitable inherent properties for high-efficiency photovoltaics, InGaN alloys exhibit several challenges to such a goal. Recent experimental work on InGaN-based solar cells have demonstrated conversion efficiency of less than $2 \%$ for both $\mathrm{InGaN} / \mathrm{GaN}$ heterostructures [12-14] and p-i-n homojunction devices [15, 16]. A major issue is p-type doping in nitride alloys.

Typical hole concentrations for p-type GaN and low-indium-content $\mathrm{InGaN}$ are in the mid-10 18 $\mathrm{cm}^{-3}$ range $[17,18]$. The growth of highly p-type layers remains challenging as a result of limited solubility of acceptors, large activation energy of acceptors, and compensation by native defects. The solubility of magnesium (Mg), commonly used as a dopant in III-nitrides, is limited by the 
formation of $\mathrm{Mg}_{3} \mathrm{~N}_{2}$ [19]. The competition between the formation of this precipitate and the incorporation of $\mathrm{Mg}$ on a $\mathrm{Ga} / \mathrm{In}$ substitutional site moderates p-doping efficiency. Recent efforts have partially overcome these thermodynamic limits by controlling the kinetics of $\mathrm{Mg}$ incorporation using a low substrate temperature and a specific growth procedure [20, 21]. These experimental studies have resulted in highly p-type III-nitride films with hole concentrations exceeding $7 \times 10^{19} \mathrm{~cm}^{-3}$ [22], offering promise for future subcells and tunnel junctions.

P-type doping in III-nitrides is also hindered by the high thermal activation energy of the Mg-acceptor. Larger activation energy lowers the ionization efficiency of dopants, which leads to lower free carrier concentration. Previous studies have reported Mg activation energy of 140$220 \mathrm{meV}$ in $\mathrm{GaN}$, which yields poor ionization efficiency of 1-5\% [23, 24]. The Mg-acceptor activation energy in p-type InGaN is lower than that in p-doped $\mathrm{GaN}$ and decreases with increasing indium composition $[25,26]$. Another limitation to the development of reliable p-type layers arises from the formation of compensating native defects [19]. Such defects, commonly attributed to nitrogen vacancies associated with dislocations [27] or oxygen, hydrogen, and silicon impurities [28], act as donors that compensate acceptors. As a result, undoped GaN and InGaN films usually display high background donor concentration. As the InN mole fraction increases, the residual electron concentration increases from $10^{16} \mathrm{~cm}^{-3}(\mathrm{GaN})$ to $10^{19} \mathrm{~cm}^{-3}(\mathrm{InN})$ [29]. This high concentration of background donors decreases p-doping efficiency.

Other unique properties of III-nitrides that influence device performance are strong spontaneous and piezoelectric polarization effects [30]. Due to the non-centrosymmetry of their wurtzite structures and a large degree of iconicity between the covalent metal and nitrogen bond, nitride semiconductors exhibit spontaneous polarization [31]. In addition, strained III-nitride materials display piezoelectric polarization. At an abrupt heterojunction interface, the discontinuity in spontaneous and piezoelectric polarization generates interface charges that produce strong band bending. In III-polar InGaN/GaN heterojunction solar cells, the polarization-induced electric field hinders carrier collection [32, 33].

Another challenge to high-efficiency InGaN solar cells is the growth of thick, high-quality InGaN layers with high indium content needed to absorb lower-energy photons. As a result of the miscibility gap between $\mathrm{InN}$ and $\mathrm{GaN}$, indium-rich $\mathrm{InGaN}$ films commonly display compositional fluctuation or complete phase separation [34]. However, advances in growth 
technology using control of surface kinetics have demonstrated the growth of high-indiumcontent InGaN throughout the miscibility gap without phase separation [35, 36]. A critical issue to the development of high-quality III-nitride films is the lack of a native substrate because of the wurtzite crystal structure of nitride semiconductors. The most widely used substrate for the growth of III-nitrides is sapphire. Because of the large thermal and lattice mismatch between sapphire and nitride semiconductors, epitaxial films grown on sapphire usually result in a high density of threading dislocations, stacking faults, and V-shaped defects. These crystalline defects can acts as shunt pathways [37] that increase leakage current and non-radiative recombination centers [38] that degrade minority carrier lifetime. The high dislocation densities can be moderated by growing a thick GaN buffer that will eliminate many defects [39]. This method allows for the growth of thin, low-indium-content InGaN layers that are completely strained to the thick $\mathrm{GaN}$ buffer. However, the growth of $\mathrm{InGaN}$ films on $\mathrm{GaN}$ beyond a critical thickness will result in strain relaxation, creating more recombination centers. The critical thickness becomes smaller as the indium composition increases due to larger lattice mismatch. According to the energy balance model, the calculated critical thickness for indium content higher than $30 \%$ is less than $2 \mathrm{~nm}$ [40], significantly limiting the absorption of light and thus, the performance of heterojunction solar cells. However, as the indium fraction exceeds $\sim 60 \%$, InGaN films exhibit a significant improvement in the crystalline quality and optical properties due to uniform full lattice-mismatch strain relaxation [41].

The high densities of recombination centers in InGaN drastically reduce the carrier diffusion length, which is a critical parameter for solar cell performance. While the diffusion length of GaAs is within the range $10-50 \mu \mathrm{m}$ [42], that of III-nitrides is typically $0.2-0.3 \mu \mathrm{m}[43,44]$. Unlike conventional solar cells that rely on the diffusion process for the collection of minority carriers, InGaN solar cells must rely on a drift process by means of built-in fields that efficiently separate minority carriers. Such drift fields can be extended by inserting an intrinsic InGaN layer between the $n$ - and p-type layers, forming a p-i-n junction [45]. The intrinsic layer sandwiched between the $\mathrm{n}$ - and p-doped layers serves as an absorbing layer. The photogenerated electronhole pairs are separated and collected by the drift process enabled by the built-in field across the intrinsic layer. The collection of photogenerated carriers greatly depends on the profile and the intensity of the internal electric field. Therefore, the thickness of the intrinsic layer is a critical parameter. The optimal thickness must account for the tradeoff between light absorption, which 
is higher in thicker layers, and carrier collection, which is higher in thinner layers. While intrinsic InGaN layers are essential for drift devices, the growth of such films is difficult since undoped-InGaN commonly exhibits n-type conductivity resulting from a high residual donor concentration. This high concentration of background donors negatively affects the width of the depletion region.

While previous simulations have already investigated the photovoltaic characteristics of InGaN-based p-i-n solar cells, few studies focused on optimizing the structure design. Chang et al. [33] demonstrated that appropriate band-engineered InGaN p-i-n solar cell structures can efficiently moderate the detrimental polarization effects. This study also investigated the influence of indium composition on the device performance, but did not consider other material and structure parameters. Feng et al. [46] conducted numerical simulations to determine the effects of indium content, thickness, and defect density of the intrinsic InGaN layer on the performance of homojunction solar cells. However, these simulations omitted major material limitations and growth issues such as appropriate p-type doping, background doping, and growth of thick InGaN. For this reason, the optimized structure proposed in [46] is not currently achievable. In the present work, we investigate the effect of indium content, thickness, and background donor concentration of the InGaN absorbing layer on the performance of InGaNbased p-i-n solar cells using the finite element analysis software APSYS [47]. We also present modified structures with suitable band engineering that improve the performance of InGaNbased solar cells. These numerical simulations aim to provide guidelines for optimizing device design given specific material characteristics and present and future material limitations.

\section{MATERIAL PARAMETERS}

The simulations are performed using the APSYS software, which solves the Poisson and carrier drift-diffusion equations. The optical and electrical properties of $\mathrm{GaN}$ and $\mathrm{InN}$ used in the simulations are listed in Table 1. The references for the parameters can be found elsewhere [48]. The band gap of the $\mathrm{In}_{\mathrm{x}} \mathrm{Ga}_{1-\mathrm{x}} \mathrm{N}$ ternary alloy can be expressed as

$$
E_{g}\left(\operatorname{In}_{x} G a_{1-x} N\right)=E_{g, I n N} x+E_{g, G a N}(1-x)-b x(1-x),
$$


where $E_{\mathrm{g}, \mathrm{InN}}=0.65 \mathrm{eV}$ and $E_{\mathrm{g}, \mathrm{GaN}}=3.42 \mathrm{eV}$ are the band gap energies of $\mathrm{InN}$ and $\mathrm{GaN}$, respectively and $b=1.43 \mathrm{eV}$ is the bowing parameter for $\operatorname{In}_{\mathrm{x}} \mathrm{Ga}_{1-\mathrm{x}} \mathrm{N}$ [49]. The electron and hole mobilities, $\mu_{\mathrm{e}}$ and $\mu_{\mathrm{h}}$, respectively, can be expressed as

$$
\boldsymbol{\mu}_{e, h}=\mu_{\min }+\left(\mu_{\max }-\mu_{\min }\right) /\left(1+\left(N / N_{g}\right)^{\gamma}\right),
$$

where $N$ is the doping concentration and $\mu_{\min }, \mu_{\max }$, and $\gamma$ are parameters specific to a given semiconductor [50]. The alloy mobility is calculated using a linear interpolation between the $\mathrm{GaN}$ and InN values. This approach does not take into account the influence of alloy disorder scattering, which reduces electron and hole mobilities. Minority carrier lifetimes of 5.4 and 6.5 ns have been measured in $\mathrm{GaN}$ and $\mathrm{InN}$, respectively [51, 52]. However, $\operatorname{In}_{\mathrm{x}} \mathrm{Ga}_{1-\mathrm{x}} \mathrm{N}$ alloys are expected to have lower lifetimes due to inferior crystal quality. Thus, a conservative 1-ns minority carrier lifetime is used over the entire $\operatorname{In}_{x} \mathrm{Ga}_{1-\mathrm{x}} \mathrm{N}$ composition. Shockley-Read-Hall and Auger recombination are included. A fixed Auger coefficient of $1.4 \times 10^{-30} \mathrm{~cm}^{6} / \mathrm{s}$ is used for electrons and holes [53]. The simulations also account for surface recombination losses at different heterointerfaces. According to experimental measurements [54-56], a front surface recombination velocity of $10^{4} \mathrm{~cm} / \mathrm{s}$ is used. The bottom and top contacts are assumed to be ohmic and the electrode coverage is $5 \%$. The absorption coefficient for each layer can be calculated by

$$
\alpha(E)=10^{5} \times \sqrt{a\left(E-E_{g}\right)+b\left(E-E_{g}\right)^{2}},
$$

where $E$ is the incoming photon energy and $a$ and $b$ are fitting parameters from experimental data $[49,57]$. Table 2 lists the fitting parameters used for the InGaN layers with various indium compositions. In addition, the devices are under a one-sun AM1.5 illumination. Front surface reflection and light trapping effects are not included. Finally, the nonlinear equations developed by Fiorentini et al. [58] are used to determine the spontaneous and piezoelectric polarization. Previous experimental studies indicate lower polarization charge density than theoretically predicted $[59,60]$. The difference between the theoretical and experimental values is attributed to partial compensation of the polarization by free carriers, fixed doping charges [61], and indium segregation [62]. To account for these screening effects, the theoretical polarization is scaled by a factor of 0.4 in agreement with previous studies [32, 59]. 
Conventional InGaN-based solar cells consist of a p-i-n double GaN heterojunction design [12-14]. This structure possesses an intrinsic InGaN absorbing layer inserted between $\mathrm{p}$ - and $\mathrm{n}$ type GaN layers. Previous numerical simulations demonstrated that polarization effects arising from the presence of heterointerfaces have a detrimental impact on the performance of the conventional III-polar $n-G a N / i-I n G a N / p-G a N$ solar cell $[32,33]$. The conversion efficiency drops because of two main factors. First, polarization charges create an electric field in the opposite direction to that of the built-in field, which is required for carrier drift. This polarization-induced field strongly affects band bending in the depletion region. The total electric field decreases, thereby reducing carrier collection efficiency. Second, polarization discontinuity creates potential barriers at the heterointerfaces, impeding carrier collection. For high-indium-composition InGaN layers that are needed for longer wavelength absorption, the conversion efficiency dramatically declines as a result of polarization effects. For these reasons, the present study focuses on asymmetric InGaN/GaN heterojunction and InGaN homojunction devices.

\section{SIMULATION RESULTS AND DISCUSSION}

\section{1. n-GaN/i-In ${ }_{x} G a_{1-x} N / p-\operatorname{In}_{0.25} G a_{0.75} N$ structure}

To address this polarization issue, we investigate the photovoltaic characteristics of asymmetric heterojunction designs based on an $\mathrm{n}-\mathrm{GaN} / \mathrm{i}-\mathrm{In}_{\mathrm{x}} \mathrm{Ga}_{1-\mathrm{x}} \mathrm{N} / \mathrm{p}-\mathrm{In}_{0.25} \mathrm{Ga}_{0.75} \mathrm{~N}$ structure. The $\mathrm{p}-\mathrm{GaN}$ layer in the conventional double $\mathrm{GaN}$ heterostructure has been replaced by a $\mathrm{p}$ $\mathrm{In}_{0.25} \mathrm{Ga}_{0.75} \mathrm{~N}$ layer that moderates the effects of the polarization effects. In addition, $\mathrm{p}$-InGaN exhibits several advantages over $\mathrm{p}-\mathrm{GaN}$ including lower $\mathrm{Mg}$ activation energy [25] and lower etching damage resulting in lower contact resistance [26]. While p-type InGaN layers with indium composition as high as $35 \%$ have been previously reported [25], $\operatorname{In}_{0.25} \mathrm{Ga}_{0.75} \mathrm{~N}$ was selected as the highest indium composition that can consistently be doped p-type. Fig. 1 depicts the $100-\mu \mathrm{m}$-wide $\mathrm{p}-\mathrm{i}-\mathrm{n}$ structure, which comprises a 1- $\mu \mathrm{m}$-thick n-GaN layer, an unintentionallydoped (UID) $\operatorname{In}_{\mathrm{x}} \mathrm{Ga}_{1-\mathrm{x}} \mathrm{N}$ layer, and a 50 -nm-thick $\mathrm{p}-\mathrm{In}_{0.25} \mathrm{Ga}_{0.75} \mathrm{~N}$ top layer. The thickness of the $\mathrm{p}$ doped layer is limited to $50 \mathrm{~nm}$ to maximize absorption in the intrinsic region. The electron and hole concentrations in the $\mathrm{n}-\mathrm{GaN}$ and $\mathrm{p}$-InGaN layers are $\sim 8 \times 10^{18} \mathrm{~cm}^{-3}$ and $\sim 4 \times 10^{18} \mathrm{~cm}^{-3}$, 
respectively. Similar hole concentrations in $\mathrm{Mg}$-doped $\operatorname{In}_{0.25} \mathrm{Ga}_{0.75} \mathrm{~N}$ have already been experimentally achieved [25]. Thus, such devices are currently feasible using state-of-the-art nitride technology.

Fig. 2 shows the energy band diagrams and the corresponding $J-V$ curves for an n-GaN/UID$\mathrm{In}_{0.25} \mathrm{Ga}_{0.75} \mathrm{~N} / \mathrm{p}-\mathrm{In}_{0.25} \mathrm{Ga}_{0.75} \mathrm{~N}$ solar cell structure with various UID-InGaN thicknesses and residual donor concentrations. As expected, no potential barriers are visible at the UID-InGaN/pInGaN homointerface. However, the influence of polarization-induced charges still remains at the $\mathrm{n}$-GaN/UID-InGaN heterointerface. The depletion width is affected by the thickness and the doping of the UID-layer. As the thickness of the UID-InGaN layer increases, the depletion region widens. For a 10-nm InGaN layer (Fig. 2(a)-(b)), the background doping has a negligible impact on the band diagram and the $J$ - $V$ curve. However, for thicker UID-InGaN films (Fig. 2(c)-(h)), the depletion region narrows as the background donor concentration increases.

Fig. 3 shows the short-circuit current density $\left(J_{\mathrm{sc}}\right)$, the open-circuit voltage $\left(V_{\text {oc }}\right)$, and the conversion efficiency $(\eta)$ as a function of the thickness of the UID-InGaN layer with various residual donor concentrations. $J_{\text {sc }}$ increases as the thickness increases, but decreases as the residual donor concentration increases. As the thickness of the UID-InGaN layer increases, the UID-InGaN layer can absorb more photons, resulting in increased photogenerated current. However, as the residual donor concentration increases, the collection efficiency drops due to narrower depletion width, leading to reduced photogenerated current. Contrary to $J_{\mathrm{sc}}, V_{\mathrm{oc}}$ slightly decreases as the thickness increases, but it rises as the residual donor concentration increases. $V_{\mathrm{oc}}$ can be expressed as

$$
V_{o c}=n k T / q \times \ln \left(J_{s c} / J_{0}+1\right)
$$

where $q$ is the elementary charge, $k$ is the Boltzmann constant, $n$ is the ideality factor, and $J_{0}$ is the saturation current. For a p-i-n solar cell, the Sah-Noyce-Shockley approximation is valid [46, $63]$ and $J_{0}$ can be expressed as

$$
J_{0}=q n_{i} W / \sqrt{\tau_{e} \tau_{h}},
$$

where $n_{\mathrm{i}}$ is the intrinsic carrier concentration, $\tau_{\mathrm{e}}$ and $\tau_{\mathrm{h}}$ are the electrons and holes lifetimes, respectively, and $W$ is the width of the depletion region. Higher background doping in the UID- 
layer leads to narrower depletion width, and thus, smaller saturation current. As a result, $V_{\mathrm{oc}}$ increases in cells with higher background donor concentration. On the other hand, $V_{\text {oc }}$ decreases in thicker cells due to larger saturation current density $J_{0}$.

The conversion efficiency $\eta$ represents the combined effects of $J_{\text {sc }}$ and $V_{\text {oc }}$. The efficiency improves as the thickness of the UID-InGaN layer increases. This enhancement in efficiency mainly results from the increase in $J_{\mathrm{sc}}$ because of the weaker influence of thickness on $V_{\mathrm{oc}}$. Since doping only slightly influences $J_{\text {sc }}$ at lower background donor concentrations, the efficiency demonstrates no significant variation for doping ranging from $10^{15} \mathrm{~cm}^{-3}$ to $10^{17} \mathrm{~cm}^{-3}$. A background donor concentration of $10^{17} \mathrm{~cm}^{-3}$ slightly improves the performance of the solar cell due to improvement in $V_{\text {oc }}$ for higher doping. However, the efficiency drastically declines as the background donor concentration reaches $10^{18} \mathrm{~cm}^{-3}$ for thicknesses higher than $200 \mathrm{~nm}$ due to decreased collection efficiency. Because of the relatively high band gap of $\operatorname{In}_{0.25} \mathrm{Ga}_{0.75} \mathrm{~N}(2.46$ $\mathrm{eV}$ ), the conversion efficiency of $\mathrm{n}-\mathrm{GaN} / \mathrm{UID}-\mathrm{In}_{0.25} \mathrm{Ga}_{0.75} \mathrm{~N} / \mathrm{p}-\mathrm{In}_{0.25} \mathrm{Ga}_{0.75} \mathrm{~N}$ devices is limited to 9.7\%. While such cells would be suitable as subcells in multijunction solar cells, they are inadequate as single-junction devices. Therefore, InGaN absorbing layers with higher indium content need to be considered to improve the conversion efficiency.

To determine the effect of the composition on the performance of $n-G a N / U I D-\operatorname{In}_{x} G a_{1-x} N / p-$ $\mathrm{In}_{0.25} \mathrm{Ga}_{0.75} \mathrm{~N}$ solar cells, indium mole fractions ranging from 25 to $75 \%$ of the UID- $\operatorname{In}_{\mathrm{x}} \mathrm{Ga}_{1-\mathrm{x}} \mathrm{N}$ layer are considered. In this study, the composition of the p-type layer remains $25 \%$ indium since the growth of p-doped InGaN with higher indium fraction is presently extremely challenging. The thickness and the residual donor concentration of the UID- $\operatorname{In}_{\mathrm{x}} \mathrm{Ga}_{1-\mathrm{x}} \mathrm{N}$ are $500 \mathrm{~nm}$ and $1 \times 10^{17}$ $\mathrm{cm}^{-3}$, respectively. These values were selected from the previous section as the currently achievable metrics yielding maximum efficiency. Fig. 4 shows the conversion efficiency as a function the composition. Efficiency initially increases due to increased photocurrent resulting from the reduced band gap of the InGaN absorbing layer, as shown by the band diagrams in Fig. 5(a) for three cells with various indium composition of the UID-layer: 25, 50, and 75\% In. Fig. 5(b) displays the optical generation rate for the structures with various indium composition of the UID-layer. The generation rate is significantly enhanced in InGaN layers with larger indium content, leading to higher photocurrent and, thus, greater conversion efficiency. However, for indium compositions higher than $30 \%$, the efficiency decreases because of two polarization 
effects. First, the polarization discontinuity creates a potential barrier at the GaN/InGaN heterointerface as illustrated in Fig. 5(a). As the indium composition increases, this polarizationinduced potential barrier becomes more prominent. The barrier height in the conduction band between the $\mathrm{n}-\mathrm{GaN}$ and the UID- $\mathrm{In}_{\mathrm{x}} \mathrm{Ga}_{1-\mathrm{x}} \mathrm{N}$ layers increases from $0.48 \mathrm{eV}$ for $\mathrm{x}=25 \%, 0.98 \mathrm{eV}$ for $\mathrm{x}=50 \%$, to $2.33 \mathrm{eV}$ for $\mathrm{x}=75 \%$. Second, the polarization-induced field that opposes drift transport increases. As the forward bias increases, the total electric field in the UID-InGaN layer decreases. The energy band of the InGaN layer flattens, therefore hindering carrier separation and enhancing recombination in the InGaN layer. This effect results in an abrupt drop in the current density, producing a knee in the $J$ - $V$ curve for indium compositions of $35 \%$ and $40 \%$ as shown in Fig. 6. For an indium composition of $40 \%$, the conversion efficiency dramatically reduces to $2 \%$. The device stops operating as a solar cell above an indium composition of $45 \%$.

In summary, the $n-G a N / i-\operatorname{In}_{x} \mathrm{Ga}_{1-\mathrm{x}} \mathrm{N} / \mathrm{p}-\mathrm{In}_{0.25} \mathrm{Ga}_{0.75} \mathrm{~N}$ solar cell structure mitigates the influence of polarization charges and potential barriers for solar cells with low indium composition. However, for solar cells with high indium compositions that are needed for longer wavelength absorption, polarization effects drastically degrade the photovoltaic performance.

\subsection{InGaN p-i-n homojunction structure}

To further mitigate the polarization effects, we study the photovoltaic performance of an InGaN p-i-n homojunction structure. Fig. 7 displays the schematic structure of the $n-\operatorname{In}_{x} \operatorname{Ga}_{1 \text { - }}$ ${ }_{x} \mathrm{~N} / \mathrm{UID}-\mathrm{In}_{\mathrm{x}} \mathrm{Ga}_{1-\mathrm{x}} \mathrm{N} / \mathrm{p}-\mathrm{In}_{\mathrm{x}} \mathrm{Ga}_{1-\mathrm{x}} \mathrm{N}$ cell used for simulations. In this design, an $\mathrm{n}-\mathrm{In}_{\mathrm{x}} \mathrm{Ga} \mathrm{1}_{1-\mathrm{x}} \mathrm{N} / \mathrm{UID}$ $\mathrm{In}_{\mathrm{x}} \mathrm{Ga}_{1-\mathrm{x}} \mathrm{N}$ homointerface replaces the $\mathrm{n}-\mathrm{GaN} / \mathrm{UID}-\mathrm{In}_{\mathrm{x}} \mathrm{Ga}_{1-\mathrm{x}} \mathrm{N}$ heterointerface in the previous structure. The indium composition throughout the cell is constant. The thicknesses and the doping concentrations of the $n$ - and p-type InGaN layers are identical to those of the previous structure. In contrast to the previous design, such devices are presently challenging to fabricate. While InGaN p-i-n homojunction solar cells with indium composition up to $20 \%$ have been previously demonstrated [16], the fabrication of p-i-n solar cells with higher indium content requires further improvements in InGaN material. Major issues include p-doping at high indium composition and growth of thick, high-quality InGaN layers. Fig. 8 shows the energy band diagrams and the $J-V$ characteristics for an $\operatorname{In}_{0.25} \mathrm{Ga}_{0.75} \mathrm{~N}$ homojunction solar cell with various thicknesses and background donor concentrations of the UID- $\operatorname{In}_{0.25} \mathrm{Ga}_{0.75} \mathrm{~N}$ layer. As expected, 
all polarization-induced barriers that hinder carrier collection have been eliminated. The depletion width displays strong dependence on the thickness and the doping of the UID-layer. Similar to the effect of doping on the band diagram of the heterojunction structure, higher background donor concentration leads to narrower depletion regions.

Fig. 9 shows the short-circuit current density $J_{\mathrm{sc}}$ of 25 , 50, and $70 \%$ InGaN p-i-n homojunction solar cells. $J_{\text {sc }}$ greatly depends on the indium composition, the thickness, and doping of the UID-layer. The short-circuit current density of a homojunction solar cell exhibits similar trends compared to that of a heterojunction device (Fig. 3(a)) indicating that the absorbing UID-InGaN layer predominantly influences $J_{\text {sc }}$ for both device structures. $J_{\text {sc }}$ reduces in cells with higher residual donor concentrations due to degraded collection efficiency. On the other hand, $J_{\mathrm{sc}}$ increases in thicker cells due to improved light absorption. $J_{\text {sc }}$ also improves for solar cells with higher indium composition due to lower band gap. Fig. 10(a) illustrates the decrease in band gap of $\mathrm{InGaN}$ as the indium content increases. Smaller band gaps allow enhanced absorption resulting in increased carrier generation rate (Fig. 10(b)) and thus, higher $J_{\text {sc. }}$ Fig. 11 displays the open-circuit voltage $V_{\text {oc }}$ as a function of the thickness of the UID-InGaN layer with various indium contents and background donor concentrations. Simulation results demonstrate that $V_{\mathrm{oc}}$ strongly depends on the background doping and the indium composition, but only slightly on the UID-layer thickness. Dependences on background doping and thickness are similar to those for the previous structure. Since the band gap represents an upper limit to the open-circuit voltage (neglecting Auger effects), $V_{\mathrm{oc}}$ decreases as the indium content increases.

Fig. 12(a)-(c) show the conversion efficiency $\eta$ as a function of UID-layer thickness for 25, 50 , and $70 \%$ InGaN solar cells with various background donor concentrations. Similar to $J_{\text {sc }}$, the efficiency increases as the thickness increases for background donor concentrations smaller than $10^{18} \mathrm{~cm}^{-3}$. The UID-layer doping only slightly affect the conversion efficiency for thin layers. However, moderate doping is beneficial to efficiency for thicker layers. This improvement in efficiency is mainly due to the increase in $V_{\mathrm{oc}}$ as the background doping increases and this effect is enhanced for solar cells with higher indium compositions. While a residual donor concentration of $10^{18} \mathrm{~cm}^{-3}$ drastically degrades the performance of 25 and $50 \%$ InGaN solar cells due to reduced $J_{\text {sc }}$, such a high doping slightly improves the performance of a $70 \%$ InGaN solar cell due to increased $V_{\mathrm{oc}}$. As the indium content increases from $25 \%$ to $50 \%, \eta$ improves similar 
to $J_{\mathrm{sc}}$. On the other hand, $\eta$ decreases as the indium content increases from $50 \%$ to $70 \%$. Therefore, a finer investigation of the influence of composition is required to determine the optimal efficiency for an InGaN single homojunction device.

Fig. 13(a)-(c) show the influence of composition and background doping on $J_{\mathrm{sc}}, V_{\mathrm{oc}}$, and $\eta$, respectively. These simulations do not include indium content higher than $70 \%$ since polarization effects at these high indium compositions create a surface inversion layer that induces lateral collection. The thickness of the UID-InGaN layer is set to $500 \mathrm{~nm}$. As the indium mole fraction increases, $J_{\mathrm{sc}}$ increases due to improved light absoption but $V_{\mathrm{oc}}$ decreases due to band gap reduction. These opposite trends lead to an optimum band gap for highest efficiency. For all background doping in the UID-layer, the maximum efficiency is within the range 14-18\% and occurs in the range 1.4 to $1.6 \mathrm{eV}$ (i.e., 53-60\% indium) as predicted for a single-junction device $[63,64]$. As the residual donor concentration increases, $J_{\mathrm{sc}}$ decreases but $V_{\mathrm{oc}}$ increases due to reduced depletion volumes. The optimal background doping, which accounts for the tradeoff between $J_{\mathrm{sc}}$ and $V_{\mathrm{oc}}$, is $10^{17} \mathrm{~cm}^{-3}$. Furthermore, as the background doping increases, the optimal band gap shifts to lower values, decreasing from $1.57 \mathrm{eV}$ for $10^{15} \mathrm{~cm}^{-3}$ to $1.47 \mathrm{eV}$ for $10^{18} \mathrm{~cm}^{-3}$ as illustrated in Fig. 14. This change can be attributed to the opposite trends of $J_{\mathrm{sc}}$ and $V_{\mathrm{oc}}$ with both indium composition and background doping as shown in Fig. 13(a) and (b). The combination of these opposite trends displaces the optimal efficiency towards higher indium compositions (i.e. lower band gaps) as the background doping increases. The optimized structure consists of an InGaN p-i-n homojunction solar cell with an indium composition of 55\% (i.e. 1.54 $\mathrm{eV}$ ), a UID-InGaN layer thickness of $500 \mathrm{~nm}$, and a residual donor concentration of $10^{17} \mathrm{~cm}^{-3}$. This homojunction with optimal parameter leads to a maximum conversion efficiency of $\sim 17 \%$, which is significantly lower than the theoretical maximum efficiency for a single-junction [65]. This efficiency is limited by presently achievable values of surface recombination velocity $\left(10^{4}\right.$ $\mathrm{cm} / \mathrm{s}$ ) and minority carrier lifetime (1 ns). Indeed, for an identical InGaN p-i-n homojunction device with unrealistic values of surface recombination velocity $(10 \mathrm{~cm} / \mathrm{s})$ and minority carrier lifetime $(1 \mu \mathrm{s})$, the conversion efficiency rises to $25.3 \%$ [66], which is closer to the ultimate efficiency. The simulation results demonstrate that the homojunction structure is the only practical design for high-efficiency single-junction InGaN solar cells. However, achieving high conversion efficiency still requires further improvements in material quality and surface 
passivation. Compared to present limits, a tenfold increase in both surface recombination velocity and minority carrier lifetime is needed to achieve efficiencies greater than $20 \%$.

\section{CONCLUSIONS}

In conclusion, we numerically investigated the photovoltaic performance of InGaN p-i-n solar cells. Simulation results show that band diagram, short circuit current density, open circuit voltage, and conversion efficiency strongly depend on indium content, thickness, and background doping of the unintentionally-doped layer for both heterojunction and homojunction structures. Because of enhanced light absorption, $J_{\text {sc }}$ increases for cells with larger thicknesses and higher indium compositions. However, as doping increases, the depletion region narrows, leading to poor collection efficiency and thus, reduced $J_{\mathrm{sc}} . V_{\mathrm{oc}}$ increases for cells with higher background donor concentrations due to reduced depletion volumes, but decreases for cells with higher indium compositions due to band gap reduction. In addition, $V_{\mathrm{oc}}$ depends only slightly on the thickness of the UID-InGaN layer. The conversion efficiency accounts for the tradeoff between the opposite trends of $J_{\mathrm{sc}}$ and $V_{\mathrm{oc}}$. For currently feasible n-GaN/UID- $\operatorname{In}_{\mathrm{x}} \mathrm{Ga}_{1-\mathrm{x}} \mathrm{N} / \mathrm{p}$ $\mathrm{In}_{0.25} \mathrm{Ga}_{0.75} \mathrm{~N}$ structures, the conversion efficiency is limited to $11.3 \%$ as a result of polarization effects that hinder carrier collection for high indium composition. These detrimental polarization effects can be eliminated by using $\operatorname{InGaN}$ p-i-n homojunction devices that are currently challenging to fabricate, but should be achievable in the future. For an optimized InGaN p-i-n homojunction solar cell with a 500-nm-thick absorbing layer, a background donor concentration of $10^{17} \mathrm{~cm}^{-3}$, and an indium content of $55 \%$, the maximum conversion efficiency is $\sim 17 \%$. This conversion efficiency is limited below the theoretical limit for single-junction devices by presently achievable surface recombination velocities $\left(10^{4} \mathrm{~cm} / \mathrm{s}\right)$ and minority carrier lifetimes (1 ns). With improved, but unrealistic values of surface recombination velocity and minority carrier lifetime, the efficiency rises to $\sim 25 \%$. Finally, simulations show that the optimal band gap shifts to lower values as the background doping increases. Hence, by using appropriate device design, the performance of InGaN solar cells can be optimized given achievable material parameters. 


\section{ACKNOWLEDGEMENTS}

This material is based upon work primarily supported by the National Science Foundation (NSF) and the Department of Energy (DOE) under NSF CA No. EEC-1041895. Any opinions, findings and conclusions or recommendations expressed in this material are those of the author(s) and do not necessarily reflect those of NSF or DOE.

\section{REFERENCES}

[1] A. Bhuiyan, K. Sugita, A. Hashimoto, A. Yamamoto, InGaN Solar Cells: Present State of the Art and Important Challenges, IEEE J. Photovolt. 2 (2012) 276-293.

[2] E. Trybus, G. Namkoong, W. Henderson, S. Burnham, W.A. Doolittle, M. Cheung, A. Cartwright, InN: A material with photovoltaic promise and challenges, J. Cryst. Growth 288 (2006) 218-224.

[3] J. Wu, When group-III nitrides go infrared: New properties and perspectives, J. Appl. Phys. 106 (2009) 011101.

[4] A.S. Bouazzi, H. Hamzaoui, B. Rezig, Theoretical possibilities of InxGa1-xN tandem PV structures, Sol. Energ. Mat. Sol. Cells 87 (2005) 595-603.

[5] L. Hsu, W. Walukiewicz, Modeling of InGaN/Si tandem solar cells, J. Appl. Phys. 104 (2008) 024507.

[6] M.E. Nell, A.M. Barnett, The spectral p-n junction model for tandem solar-cell design, IEEE Trans. Electron Devices ED-34 (1987) 257-266.

[7] J.F. Muth, A.J.H. Lee, I.K. Shmagin, R.M. Kolbas, H.C. Casey, Jr., B.P. Keller, U.K. Mishra, S.P. DenBaars, Absorption coefficient, energy gap, exciton binding energy, and recombination lifetime of GaN obtained from transmission measurements, Appl. Phys. Lett. 71 (1997) 2572-2574.

[8] R. Singh, D. Doppalapudi, T.D. Moustakas, L.T. Romano, Phase separation in InGaN thick films and formation of InGaN/GaN double heterostructures in the entire alloy composition, Appl. Phys. Lett. 70 (1997) 1089-1091.

[9] T.H. Wang, T.F. Ciszek, C.R. Schwerdtfeger, H. Moutinho, R. Matson, Growth of silicon thin layers on cast MG-Si from metal solutions for solar cells, Sol. Energ. Mat. Sol. Cells 41-42 (1996) 19-30.

[10] Y. Nanishi, Y. Saito, T. Yamaguchi, RF-molecular beam epitaxy growth and properties of InN and related alloys, Jpn. J. Appl. Phys. 42 (2003) 2549-2559. 
[11] J. Wu, W. Walukiewicz, K.M. Yu, W. Shan, J.W. Ager, E.E. Haller, L. Hai, W.J. Schaff, W.K. Metzger, S. Kurtz, Superior radiation resistance of In1-xGaxN alloys: Full-solar-spectrum photovoltaic material system, J. Appl. Phys. 94 (2003) 6477-6482.

[12] J.R. Lang, C.J. Neufeld, C.A. Hurni, S.C. Cruz, E. Matioli, U.K. Mishra, J.S. Speck, High external quantum efficiency and fill-factor InGaN/GaN heterojunction solar cells grown by NH3-based molecular beam epitaxy, Appl. Phys. Lett. 98 (2011) 131115.

[13] E. Matioli, C. Neufeld, M. Iza, S.C. Cruz, A.A. Al-Heji, C. Xu, R.M. Farrell, S. Keller, S. DenBaars, U. Mishra, S. Nakamura, J. Speck, C. Weisbuch, High internal and external quantum efficiency InGaN/GaN solar cells, Appl. Phys. Lett. 98 (2011) 021102.

[14] J.P. Shim, M. Choe, S.R. Jeon, D. Seo, T. Lee, D.S. Lee, InGaN-Based p-i-n Solar Cells with Graphene Electrodes, Appl. Phys. Express 4 (2011) 052302.

[15] L. Sang, M. Liao, N. Ikeda, Y. Koide, M. Sumiya, Enhanced performance of InGaN solar cell by using a super-thin AlN interlayer, Appl. Phys. Lett. 99 (2011) 161109.

[16] X.-M. Cai, S.-W. Zeng, B.-P. Zhang, Fabrication and characterization of InGaN p-i-n homojunction solar cell, Appl. Phys. Lett. 95 (2009) 173504.

[17] S.-N. Lee, T. Sakong, W. Lee, H. Paek, J. Son, E. Yoon, O. Nam, Y. Park, Characterization of optical and electrical quality of Mg-doped InxGa1-xN grown by MOCVD, J. Cryst. Growth 261 (2004) 249-252.

[18] S. Brochen, J. Brault, S. Chenot, A. Dussaigne, M. Leroux, B. Damilano, Dependence of the $\mathrm{Mg}$-related acceptor ionization energy with the acceptor concentration in p-type GaN layers grown by molecular beam epitaxy, Appl. Phys. Lett. 103 (2013) 032102.

[19] C.G. Van de Walle, C. Stampfl, J. Neugebauer, Theory of doping and defects in III-V nitrides, J. Cryst. Growth 189-190 (1998) 505-510.

[20] G. Namkoong, E. Trybus, K.K. Lee, M. Moseley, W.A. Doolittle, D.C. Look, Metal modulation epitaxy growth for extremely high hole concentrations above $1019 \mathrm{~cm}-3$ in GaN, Appl. Phys. Lett. 93 (2008) 172112.

[21] E. Trybus, W.A. Doolittle, M. Moseley, W. Henderson, D. Billingsley, G. Namkoong, D.C. Look, Extremely high hole concentrations in c-plane GaN, Phys. Status Solidi C 6 (2009) S788-S791.

[22] B. Gunning, J. Lowder, M. Moseley, W.A. Doolittle, Negligible carrier freeze-out facilitated by impurity band conduction in highly p-type GaN, Appl. Phys. Lett. 101 (2012) 082106.

[23] S. Fischer, C. Wetzel, E.E. Haller, B.K. Meyer, On p-type doping in GaN-acceptor binding energies, Appl. Phys. Lett. 67 (1995) 1298-1300. 
[24] A. Bhattacharyya, W. Li, J. Cabalu, T.D. Moustakas, D.J. Smith, R.L. Hervig, Efficient p-type doping of GaN films by plasma-assisted molecular beam epitaxy, Appl. Phys. Lett. 85 (2004) 4956-4958.

[25] B.N. Pantha, A. Sedhain, J. Li, J.Y. Lin, H.X. Jiang, Electrical and optical properties of p-type InGaN, Appl. Phys. Lett. 95 (2009) 261904.

[26] K. Kumakura, T. Makimoto, N. Kobayashi, Mg-acceptor activation mechanism and transport characteristics in p-type InGaN grown by metalorganic vapor phase epitaxy, J. Appl. Phys. 93 (2003) 3370-3375.

[27] D.C. Look, D.C. Reynolds, J.W. Hemsky, J.R. Sizelove, R.L. Jones, R.J. Molnar, Defect Donor and Acceptor in GaN, Phys. Rev. Lett. 79 (1997) 2273-2276.

[28] S. Nakamura, N. Iwasa, M. Senoh, T. Mukai, Hole compensation mechanism of P-type GaN films, Jpn. J. Appl. Phys. 31 (1992) 1258-1266.

[29] B.N. Pantha, H. Wang, N. Khan, J.Y. Lin, H.X. Jiang, Origin of background electron concentration in InxGa1-xN alloys, Phys. Rev. B 84 (2011) 075327.

[30] E.T. Yu, X.Z. Dang, P.M. Asbeck, S.S. Lau, G.J. Sullivan, Spontaneous and piezoelectric polarization effects in III-V nitride heterostructures, J. Vac. Sci. Technol. B 17 (1999) 17421749 .

[31] S.Y. Karpov, Spontaneous polarization in III-nitride materials: crystallographic revision, Phys. Status Solidi C 7 (2010) 1841-1843.

[32] Z.Q. Li, M. Lestradet, Y.G. Xiao, S. Li, Effects of polarization charge on the photovoltaic properties of InGaN solar cells, Phys. Status Solidi A 208 (2011) 928-931.

[33] J.-Y. Chang, S.-H. Yen, Y.-A. Chang, Y.-K. Kuo, Simulation of high-efficiency $\mathrm{GaN} / \mathrm{InGaN}$ p-i-n solar cell with suppressed polarization and barrier effects, IEEE J. Quantum Electron. 49 (2013) 17-23.

[34] G.B. Stringfellow, Microstructures produced during the epitaxial growth of InGaN alloys, J. Cryst. Growth 312 (2010) 735-749.

[35] M. Moseley, J. Lowder, D. Billingsley, W.A. Doolittle, Control of surface adatom

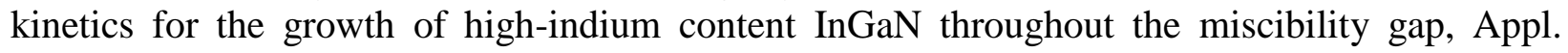
Phys. Lett. 97 (2010) 191902.

[36] M. Moseley, B. Gunning, J. Greenlee, J. Lowder, G. Namkoong, W.A. Doolittle, Observation and control of the surface kinetics of $\mathrm{InGaN}$ for the elimination of phase separation, J. Appl. Phys. 112 (2012) 014909.

[37] P. Kozodoy, J.P. Ibbetson, H. Marchand, P.T. Fini, S. Keller, J.S. Speck, S.P. DenBaars, U.K. Mishra, Electrical characterization of GaN p-n junctions with and without threading dislocations, Appl. Phys. Lett. 73 (1998) 975-977. 
[38] J. Abell, T.D. Moustakas, The role of dislocations as nonradiative recombination centers in InGaN quantum wells, Appl. Phys. Lett. 92 (2008) 091901.

[39] J. Jasinski, Z. Liliental-Weber, Extended defects and polarity of hydride vapor phase epitaxy GaN, Journal of Electronic Materials 31 (2002) 429-436.

[40] D. Holec, P.M.F.J. Costa, M.J. Kappers, C.J. Humphreys, Critical thickness calculations for InGaN/GaN, J. Cryst. Growth 303 (2007) 314-317.

[41] A.M. Fischer, Y.O. Wei, F.A. Ponce, M. Moseley, B. Gunning, W.A. Doolittle, Highly luminescent, high-indium-content InGaN film with uniform composition and full misfit-strain relaxation, Appl. Phys. Lett. 103 (2013) 131101.

[42] M.R. Brozel, G.E. Stillman, Properties of Gallium Arsenide, third ed., Institution of Engineering and Technology, London, 1996.

[43] K. Kumakura, T. Makimoto, N. Kobayashi, T. Hashizume, T. Fukui, H. Hasegawa, Minority carrier diffusion length in GaN: dislocation density and doping concentration dependence, Appl. Phys. Lett. 86 (2005) 52105.

[44] Z.Z. Bandić, P.M. Bridger, E.C. Piquette, T.C. McGill, The values of minority carrier diffusion lengths and lifetimes in $\mathrm{GaN}$ and their implications for bipolar devices, Solid-State Electron. 44 (2000) 221-228.

[45] J. Poortmans, V. Arkhipov, Thin film solar cells: fabrication, characterization and applications, Wiley, Chichester, England, 2006.

[46] S.-W. Feng, C.-M. Lai, C.-H. Chen, W.-C. Sun, L.-W. Tu, Theoretical simulations of the effects of the indium content, thickness, and defect density of the i-layer on the performance of p-i-n InGaN single homojunction solar cells, J. Appl. Phys. 108 (2010) 093118.

[47] APSYS Crosslight Software Inc. Online. Available from URL: http://www.crosslight.com

[48] G.F. Brown, J.W. Ager III, W. Walukiewicz, J. Wu, Finite element simulations of compositionally graded InGaN solar cells, Sol. Energ. Mat. Sol. Cells 94 (2010) 478-483.

[49] J. Wu, W. Walukiewicz, K.M. Yu, J.W. Ager, E.E. Haller, L. Hai, W.J. Schaff, Small band gap bowing in In1-xGaxN alloys, Appl. Phys. Lett. 80 (2002) 4741-4743.

[50] D.M. Caughey, R.E. Thomas, Carrier mobilities in silicon empirically related to doping and field, Proceedings of the IEEE 55 (1967) 2192-2193.

[51] Z.Z. Bandic, P.M. Bridger, E.C. Piquette, T.C. McGill, Minority carrier diffusion length and lifetime in GaN, Appl. Phys. Lett. 72 (1998) 3166-3168.

[52] F. Chen, A.N. Cartwright, H. Lu, W.J. Schaff, Temperature dependence of carrier lifetimes in InN, Phys. Status Solidi A 202 (2005) 768-772. 
[53] Y.C. Shen, G.O. Mueller, S. Watanabe, N.F. Gardner, A. Munkholm, M.R. Krames, Auger recombination in InGaN measured by photoluminescence, Appl. Phys. Lett. 91 (2007) 141101.

[54] P. Scajev, K. Jarasiunas, S. Okur, U. Ozgur, H. Morkoc, Carrier dynamics in bulk GaN, J. Appl. Phys. 111 (2012) 023702.

[55] M. Boroditsky, I. Gontijo, M. Jackson, R. Vrijen, E. Yablonovitch, T. Krauss, C.-C. Cheng, A. Scherer, R. Bhat, M. Krames, Surface recombination measurements on III-V candidate materials for nanostructure light-emitting diodes, J. Appl. Phys. 87 (2000) 3497-3504.

[56] H. Kitagawa, T. Suto, M. Fujita, Y. Tanaka, T. Asano, S. Noda, Green Photoluminescence from GaInN Photonic Crystals, Appl. Phys. Express 1 (2008) 032004.

[57] W. Walukiewicz, J.W. Ager III, K.M. Yu, Z. Liliental-Weber, J. Wu, S.X. Li, R.E. Jones, J.D. Denlinger, Structure and electronic properties of InN and In-rich group III-nitride alloys J. Phys. D Appl. Phys. 39 (2006) R83-R99.

[58] V. Fiorentini, F. Bernardini, O. Ambacher, Evidence for nonlinear macroscopic polarization in III-V nitride alloy heterostructures, Appl. Phys. Lett. 80 (2002) 1204-1206.

[59] H. Zhang, E.J. Miller, E.T. Yu, C. Poblenz, J.S. Speck, Measurement of polarization charge and conduction-band offset at InxGa1-xN/GaN heterojunction interfaces, Appl. Phys. Lett. 84 (2004) 4644-4646.

[60] C.A. Flory, G. Hasnain, Modeling of $\mathrm{GaN}$ optoelectronic devices and strain-induced piezoelectric effects, IEEE J. Quantum Electron. 37 (2001) 244-253.

[61] F.D. Sala, A.D. Carlo, P. Lugli, R. Cingolani, G. Coli', M. Lomascolo, A. Botchkarev, H. Tang, H. Morkoc, Carrier screening and polarization fields in nitride-based heterostructure devices, Physica B 272 (1999) 397-401.

[62] O. Mayrock, H.J. Wunsche, F. Henneberger, Polarization charge screening and indium surface segregation in (In, Ga)N/GaN single and multiple quantum wells, Phys. Rev. B 62 (2000) 16870-16880.

[63] J. Nelson, The Physics of Solar Cells, Imperial College Press, UK, 2003.

[64] M.A. Green, Solar cells: operating principles, technology, and system applications, Prentice-Hall, Englewood Cliffs, NJ, 1982.

[65] M.A. Green, Limiting photovoltaic efficiency under new ASTM International G173based reference spectra, Prog. Photovoltaics 20 (2012) 954-959.

[66] C. Fabien, M. Moseley, B. Gunning, W.A. Doolittle, A.M. Fischer, Y.O. Wei, F.A. Ponce, Simulations, practical limitations and novel growth technology for InGaN-based solar cells, IEEE J. Photovolt. 4 (2013) 601-606. 


\section{LIST OF TABLES}

Table 1. Parameters of $\mathrm{GaN}$ and $\mathrm{InN}$ used in the simulations.

\begin{tabular}{lll}
\hline Parameter & $\mathrm{GaN}$ & $\mathrm{InN}$ \\
\hline Band gap $E_{\mathrm{g}}(\mathrm{eV})$ & 3.42 & 0.65 \\
Dielectric constant $\varepsilon_{\mathrm{s}} / \varepsilon_{0}$ & 8.9 & 10.5 \\
Electron mass $m_{\mathrm{e}} / m_{0}$ & 0.2 & 0.05 \\
Hole mass $m_{\mathrm{h}} / m_{0}$ & 1.25 & 0.6 \\
Electron affinity $E_{a}(\mathrm{eV})$ & 4 & 5.6 \\
Electron lifetime $\tau_{\mathrm{e}}(\mathrm{ns})$ & 1 & 1 \\
Hole lifetime $\tau_{\mathrm{h}}(\mathrm{ns})$ & 1 & 1 \\
$\mu_{\min , \mathrm{e}}\left(\mathrm{cm}^{2} \mathrm{~V}^{-1} \mathrm{~s}^{-1}\right)$ & 55 & 30 \\
$\mu_{\max , \mathrm{e}}\left(\mathrm{cm}^{2} \mathrm{~V}^{-1} \mathrm{~s}^{-1}\right)$ & 1000 & 1100 \\
$\gamma_{\mathrm{e}}$ & 1 & 1 \\
$N_{\mathrm{g}, \mathrm{e}}\left(\mathrm{cm}^{-3}\right)$ & $2 \times 10^{17}$ & $8 \times 10^{18}$ \\
$\mu_{\mathrm{min}, \mathrm{h}}\left(\mathrm{cm}^{2} \mathrm{~V}^{-1} \mathrm{~s}^{-1}\right)$ & 3 & 3 \\
$\mu_{\mathrm{max}, \mathrm{h}}\left(\mathrm{cm}^{2} \mathrm{~V}^{-1} \mathrm{~s}^{-1}\right)$ & 170 & \\
$\gamma_{\mathrm{h}}$ & 2 & 2 \\
$N_{\mathrm{g}, \mathrm{h}}\left(\mathrm{cm}^{-3}\right)$ & $3 \times 10^{17}$ & $3 \times 10^{17}$
\end{tabular}

Table 2. Fitting parameters used to calculate the absorption coefficients.

\begin{tabular}{lll}
\hline Indium composition & $a$ & $b$ \\
\hline 0 & 3.52517 & -0.657999 \\
0.25 & 2.02095 & -0.094817 \\
0.50 & 0.51672 & 0.468365 \\
0.75 & 0.61831 & 0.677523 \\
1 & 0.69642 & 0.460553
\end{tabular}




\section{LIST OF FIGURE CAPTIONS}

Fig. 1. Schematic structure of an $n-G a N / U I D-\operatorname{In}_{x} G_{1-x} N / p-\operatorname{In}_{0.25} \mathrm{Ga}_{0.75} \mathrm{~N}$ heterojunction solar cell.

Fig. 2. (a), (c), (e), (g) Energy band diagrams at equilibrium for an n-GaN/UID- $\operatorname{In}_{0.25} \mathrm{Ga}_{0.75} \mathrm{~N} / \mathrm{p}$ $\mathrm{In}_{0.25} \mathrm{Ga}_{0.75} \mathrm{~N}$ structure with various UID-InGaN thicknesses: $10 \mathrm{~nm}, 50 \mathrm{~nm}, 100 \mathrm{~nm}$, and $500 \mathrm{~nm}$, respectively. (b), (d), (f), (h) Corresponding $J-V$ characteristics under AM1.5 illumination. The depletion width is affected by the thickness and the doping of the UID-layer.

Fig. 3. (a) Short circuit current $J_{\mathrm{sc}}$, (b) open-circuit voltage $V_{\mathrm{oc}}$, and (c) conversion efficiency $\eta$ as a function of the UID-layer thickness for an $\mathrm{n}-\mathrm{GaN} / \mathrm{UID}-\mathrm{In}_{0.25} \mathrm{Ga}_{0.75} \mathrm{~N} / \mathrm{p}-\mathrm{In}_{0.25} \mathrm{Ga}_{0.75} \mathrm{~N}$ solar cell with various concentrations of background donors.

Fig. 4. Conversion efficiency $\eta$ of an $n-G a N / U I D-\operatorname{In}_{x} G_{1-x} N / p-\operatorname{In}_{0.25} G_{0.75} N$ structure as a function of the indium composition (i.e., band gap) in the UID-InGaN layer. The efficiency is limited to $11.3 \%$ because of polarization effects.

Fig. 5. (a) Band diagrams at equilibrium and (b) optical carrier generation rates for an nGaN/UID- $\operatorname{In}_{\mathrm{x}} \mathrm{Ga}_{1-\mathrm{x}} \mathrm{N} / \mathrm{p}-\mathrm{In}_{0.25} \mathrm{Ga}_{0.75} \mathrm{~N}$ structure with various indium composition in the UID-layer. While the generation rate is enhanced for InGaN layers with higher indium content, the polarization effects hinder the collection of photogenerated carriers.

Fig. 6. $J-V$ characteristics under AM1.5 illumination for an $n-G a N / U I D-I_{x} G a_{1-x} N / p-$ $\mathrm{In}_{0.25} \mathrm{Ga}_{0.75} \mathrm{~N}$ structure with various indium composition in the UID-layer. The polarizationinduced electric field produces a knee in the IV curve for indium compositions of $35 \%$ and $40 \%$. Above an indium composition of $45 \%$, the device stops operating as a solar cell.

Fig. 7. Schematic structure of an $n-\operatorname{In}_{x} \mathrm{Ga}_{1-\mathrm{x}} \mathrm{N} / \mathrm{UID}-\mathrm{In}_{\mathrm{x}} \mathrm{Ga}_{1-\mathrm{x}} \mathrm{N} / \mathrm{p}-\mathrm{In}_{\mathrm{x}} \mathrm{Ga}_{1-\mathrm{x}} \mathrm{N}$ homojunction solar cell.

Fig. 8. (a), (c), (e), (g) Energy band diagrams at equilibrium for an $n-\operatorname{In}_{0.25} \mathrm{Ga}_{0.75} \mathrm{~N} / \mathrm{UID}$ $\mathrm{In}_{0.25} \mathrm{Ga}_{0.75} \mathrm{~N} / \mathrm{p}-\mathrm{In}_{0.25} \mathrm{Ga}_{0.75} \mathrm{~N}$ structure with various UID-InGaN thicknesses: $10 \mathrm{~nm}, 50 \mathrm{~nm}, 100$ $\mathrm{nm}$, and $500 \mathrm{~nm}$, respectively. (b), (d), (f), (h) Corresponding $J-V$ characteristics under AM1.5 illumination.

Fig. 9. Short circuit current $J_{\mathrm{sc}}$ as a function of UID-layer thickness for an $n-\mathrm{In}_{\mathrm{x}} \mathrm{Ga} \mathrm{a}_{1-\mathrm{x}} \mathrm{N} / \mathrm{UID}$ $\mathrm{In}_{\mathrm{x}} \mathrm{Ga}_{1-\mathrm{x}} \mathrm{N} / \mathrm{p}-\mathrm{In}_{\mathrm{x}} \mathrm{Ga}_{1-\mathrm{x}} \mathrm{N}$ solar cell with various indium compositions and concentrations of background donors. $J_{\text {sc }}$ increases for cells with larger thickness and higher indium content because of enhanced light absorption, but decreases for cells with higher background doping because of reduced collection efficiency.

Fig. 10. (a) Band diagrams at equilibrium and (b) optical carrier generation rate under AM1.5 illumination for an $n-\operatorname{In}_{x} G_{1-x} N / U I D-\operatorname{In}_{x} G_{1-x} N / p-\operatorname{In}_{x} G_{a} a_{1-x} N$ structure with various indium compositions. 
Fig. 11. Open-circuit voltage $V_{\text {oc }}$ as a function of UID-layer thickness for an $n-\operatorname{In}_{\mathrm{x}} \mathrm{Ga} \mathrm{a}_{1-\mathrm{x}} \mathrm{N} / \mathrm{UID}$ $\mathrm{In}_{\mathrm{x}} \mathrm{Ga}_{1-\mathrm{x}} \mathrm{N} / \mathrm{p}-\mathrm{In}_{\mathrm{x}} \mathrm{Ga}_{1-\mathrm{x}} \mathrm{N}$ solar cell with various indium compositions and concentrations of background donors. $V_{\text {oc }}$ decreases for cells with higher indium content due to reduced band gap, but increases for cells with higher background doping due to narrower depletion width.

Fig. 12. Conversion efficiency $\eta$ as a function of UID-layer thickness for (a) $\operatorname{In}_{0.25} \mathrm{Ga}_{0.75} \mathrm{~N}$ (b) $\mathrm{In}_{0.50} \mathrm{Ga}_{0.50} \mathrm{~N}$ (c) $\mathrm{In}_{0.70} \mathrm{Ga}_{0.30} \mathrm{~N}$ p-i-n homojunction solar cells with various concentrations of background donors. The conversion efficiency accounts for the tradeoff between the opposite trends of $J_{\mathrm{sc}}$ and $V_{\mathrm{oc}}$.

Fig. 13. (a) Short circuit current $J_{\mathrm{sc}}$, (b) open-circuit voltage $V_{\mathrm{oc}}$, and (c) conversion efficiency $\eta$ as a function of indium composition (i.e. band gap) for an $n-\operatorname{In}_{\mathrm{x}} \mathrm{Ga}_{1-\mathrm{x}} \mathrm{N} / \mathrm{UID}-\mathrm{In}_{\mathrm{x}} \mathrm{Ga} a_{1-\mathrm{x}} \mathrm{N} / \mathrm{p}-\mathrm{In}_{\mathrm{x}} \mathrm{Ga}_{1-}$ ${ }_{\mathrm{x}} \mathrm{N}$ structure with various residual donor concentrations. The thickness of the UID-InGaN is 500 $\mathrm{nm}$.

Fig. 14. Optimal indium composition and band gap as a function of background doping in the UID-InGaN layer for an $n-\operatorname{In}_{x} G_{1-x} N / U I D-\operatorname{In}_{x} G a_{1-x} N / p-\operatorname{In}_{x} G a_{1-x} N$ structure. As the background doping increases, the optimal band gap shifts to lower values. 


\section{LIST OF FIGURES}

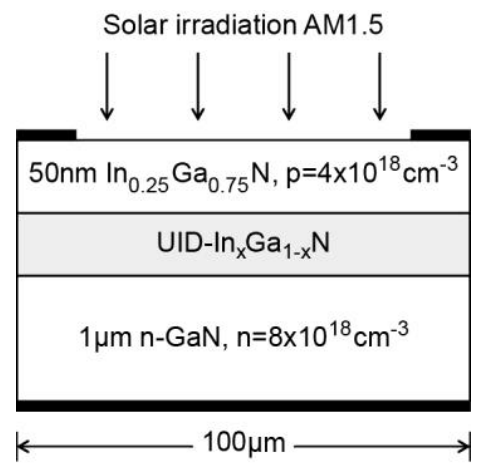

Fig. 15. Schematic structure of an $n-G a N / U I D-\operatorname{In}_{x} \mathrm{Ga}_{1-\mathrm{x}} \mathrm{N} / \mathrm{p}-\mathrm{In}_{0.25} \mathrm{Ga}_{0.75} \mathrm{~N}$ heterojunction solar cell. 

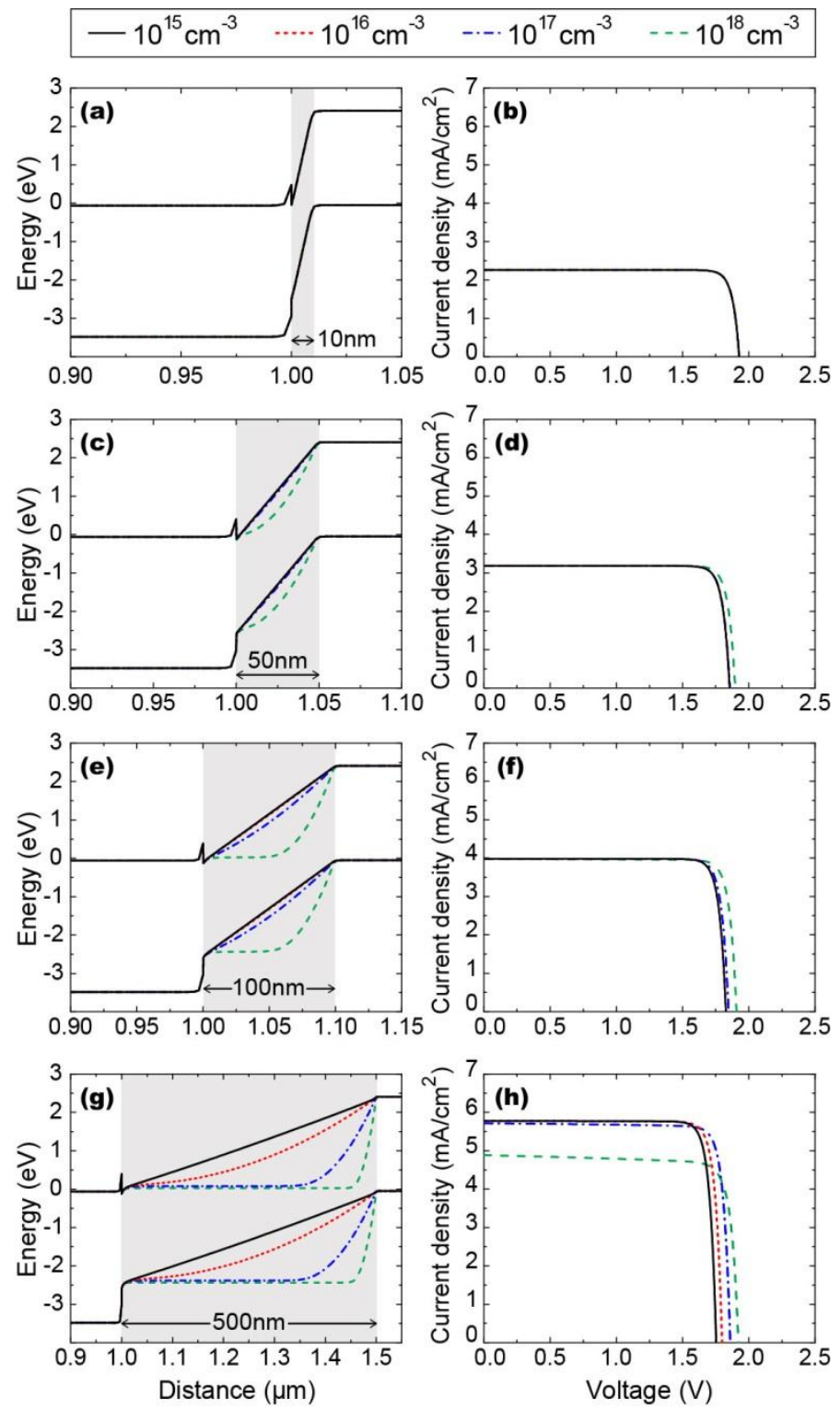

Fig. 16. (a), (c), (e), (g) Energy band diagrams at equilibrium for an $n-G a N / U I D-I_{0.25} \mathrm{Ga}_{0.75} \mathrm{~N} / \mathrm{p}-$ $\mathrm{In}_{0.25} \mathrm{Ga}_{0.75} \mathrm{~N}$ structure with various UID-InGaN thicknesses: $10 \mathrm{~nm}, 50 \mathrm{~nm}, 100 \mathrm{~nm}$, and $500 \mathrm{~nm}$, respectively. (b), (d), (f), (h) Corresponding $J-V$ characteristics under AM1.5 illumination. The depletion width is affected by the thickness and the doping of the UID-layer. 


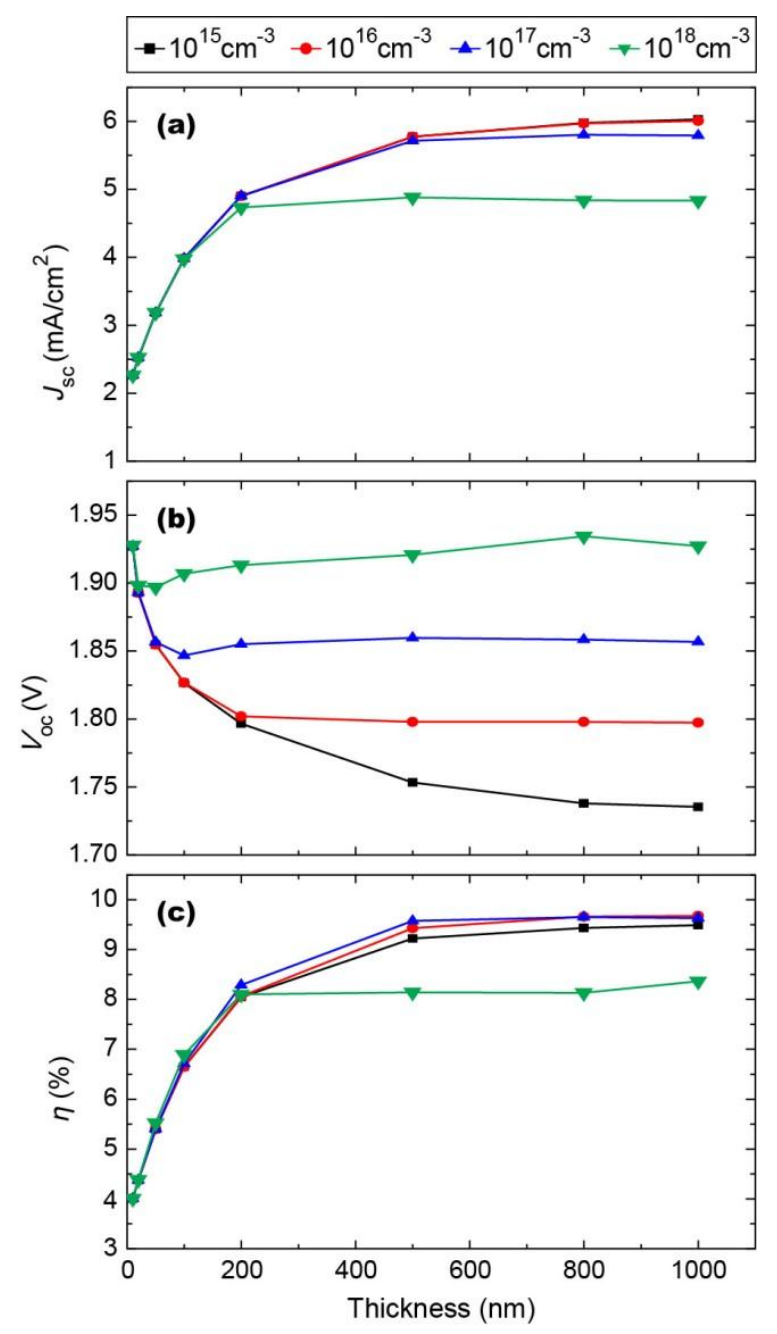

Fig. 17. (a) Short circuit current $J_{\text {sc }}$, (b) open-circuit voltage $V_{\text {oc }}$, and (c) conversion efficiency $\eta$ as a function of the UID-layer thickness for an $\mathrm{n}-\mathrm{GaN} / \mathrm{UID}-\mathrm{In}_{0.25} \mathrm{Ga}_{0.75} \mathrm{~N} / \mathrm{p}-\mathrm{In}_{0.25} \mathrm{Ga}_{0.75} \mathrm{~N}$ solar cell with various concentrations of background donors. 


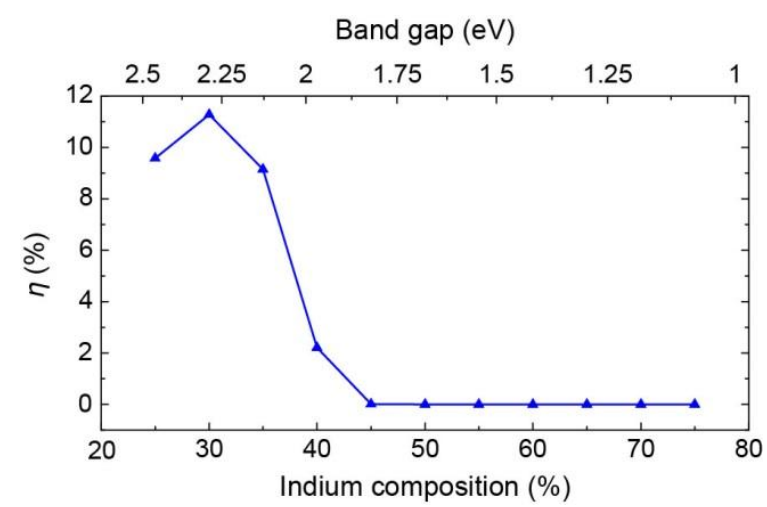

Fig. 18. Conversion efficiency $\eta$ of an $n-G a N / U I D-\operatorname{In}_{x} G a_{1-x} N / p-\operatorname{In}_{0.25} G_{0.75} \mathrm{~N}$ structure as a function of the indium composition (i.e., band gap) in the UID-InGaN layer. The efficiency is limited to $11.3 \%$ because of polarization effects.
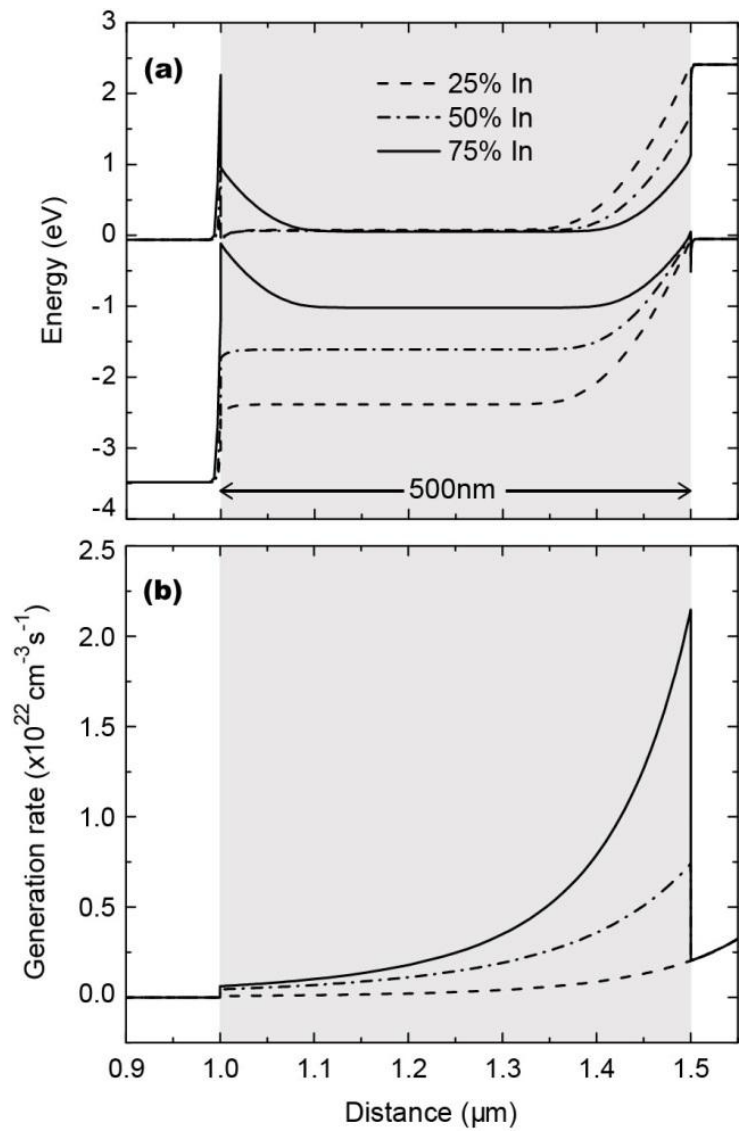

Fig. 19. (a) Band diagrams at equilibrium and (b) optical carrier generation rates for an n$\mathrm{GaN} / \mathrm{UID}-\mathrm{In}_{\mathrm{x}} \mathrm{Ga}_{1-\mathrm{x}} \mathrm{N} / \mathrm{p}-\mathrm{In}_{0.25} \mathrm{Ga}_{0.75} \mathrm{~N}$ structure with various indium composition in the UID-layer. While the generation rate is enhanced for InGaN layers with higher indium content, the polarization effects hinder the collection of photogenerated carriers. 


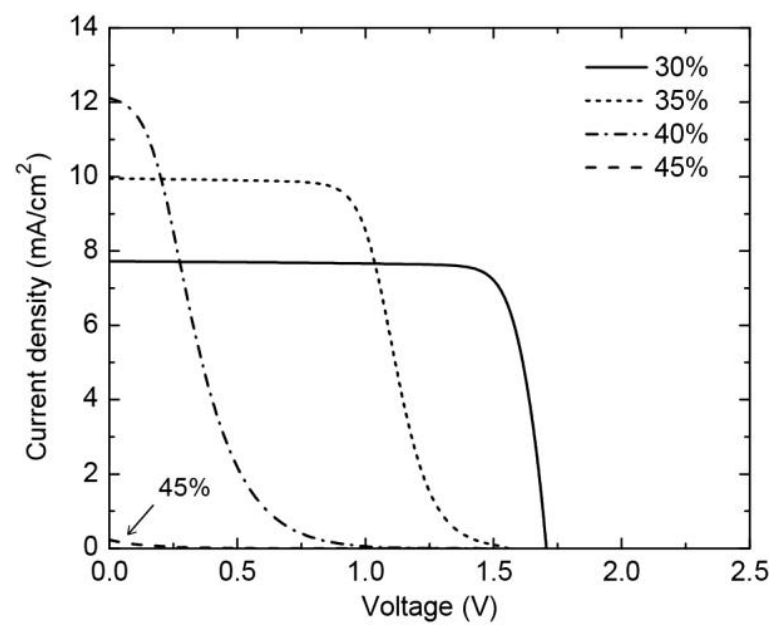

Fig. 20. $J-V$ characteristics under AM1.5 illumination for an $n-G a N / U I D-\operatorname{In}_{x} G a_{1-x} N / p-$ $\operatorname{In}_{0.25} \mathrm{Ga}_{0.75} \mathrm{~N}$ structure with various indium composition in the UID-layer. The polarizationinduced electric field produces a knee in the IV curve for indium compositions of 35\% and $40 \%$. Above an indium composition of $45 \%$, the device stops operating as a solar cell.

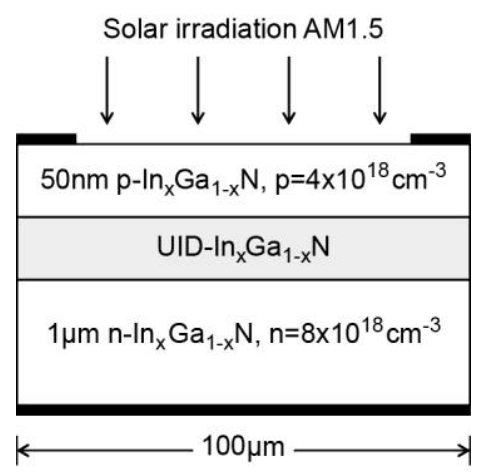

Fig. 21. Schematic structure of an $n-\operatorname{In}_{x} G a_{1-x} N / U I D-\operatorname{In}_{x} G a_{1-x} N / p-\operatorname{In}_{x} G a_{1-x} N$ homojunction solar cell. 

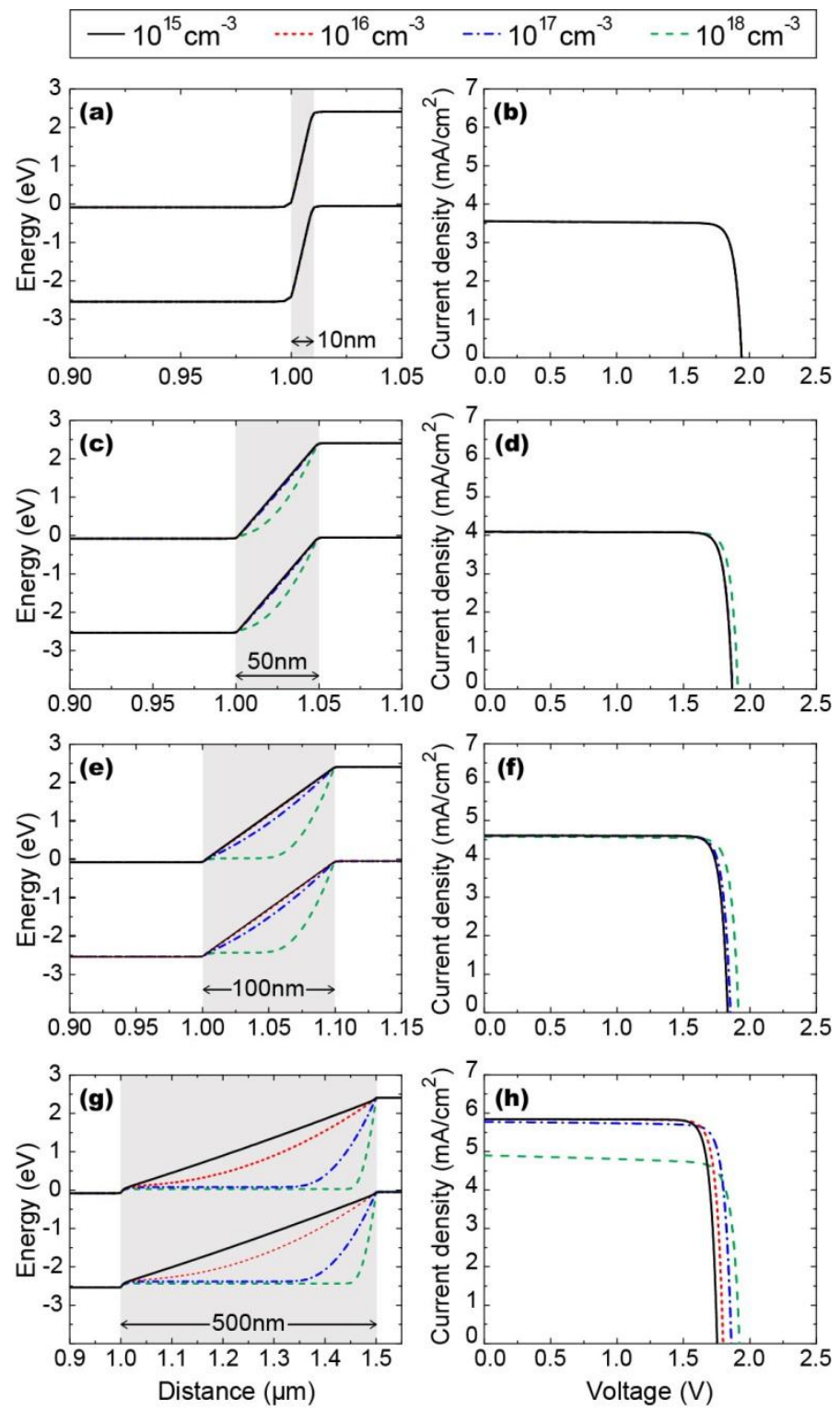

Fig. 22. (a), (c), (e), (g) Energy band diagrams at equilibrium for an $n-\operatorname{In}_{0.25} \mathrm{Ga}_{0.75} \mathrm{~N} / \mathrm{UID}$ $\mathrm{In}_{0.25} \mathrm{Ga}_{0.75} \mathrm{~N} / \mathrm{p}-\mathrm{In}_{0.25} \mathrm{Ga}_{0.75} \mathrm{~N}$ structure with various UID-InGaN thicknesses: $10 \mathrm{~nm}, 50 \mathrm{~nm}, 100$ $\mathrm{nm}$, and $500 \mathrm{~nm}$, respectively. (b), (d), (f), (h) Corresponding $J-V$ characteristics under AM1.5 illumination. 


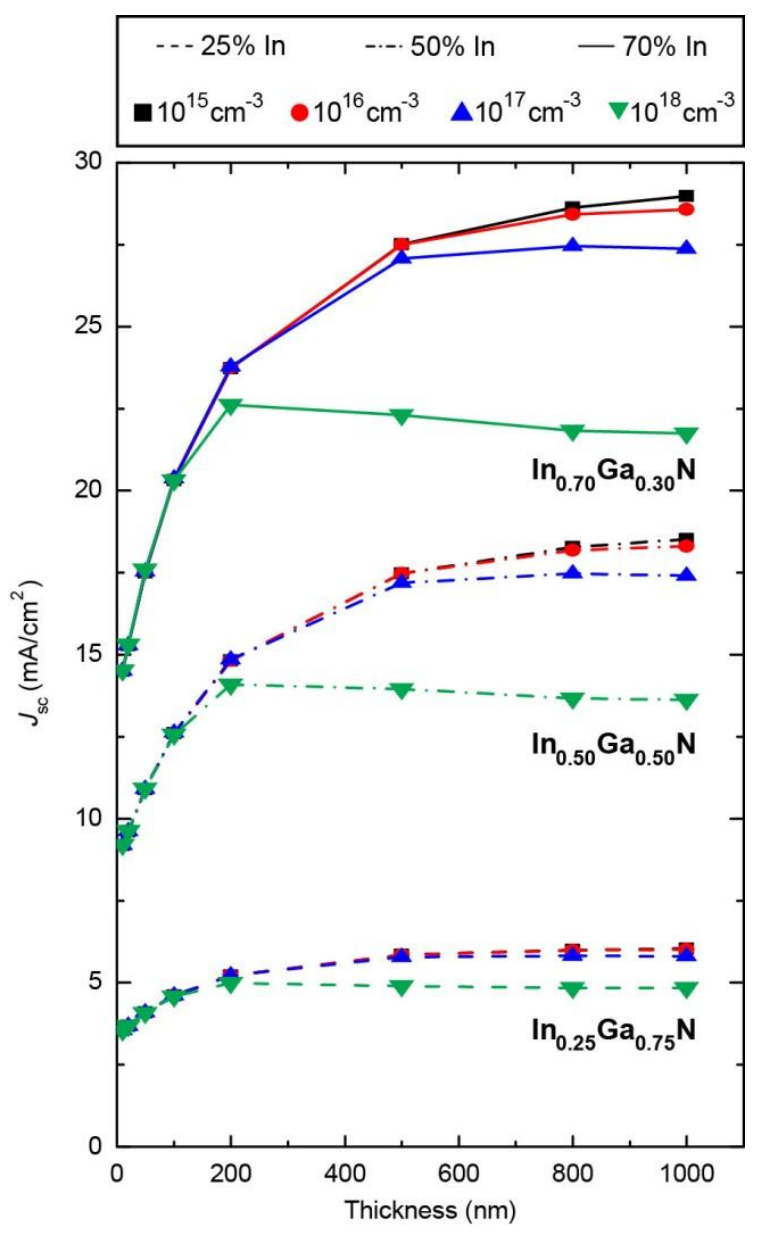

Fig. 23. Short circuit current $J_{\mathrm{sc}}$ as a function of UID-layer thickness for an $n-\operatorname{In}_{\mathrm{x}} \mathrm{Ga} a_{1-\mathrm{x}} \mathrm{N} / \mathrm{UID}$ $\mathrm{In}_{\mathrm{x}} \mathrm{Ga}_{1-\mathrm{x}} \mathrm{N} / \mathrm{p}-\mathrm{In}_{\mathrm{x}} \mathrm{Ga}_{1-\mathrm{x}} \mathrm{N}$ solar cell with various indium compositions and concentrations of background donors. $J_{\text {sc }}$ increases for cells with larger thickness and higher indium content because of enhanced light absorption, but decreases for cells with higher background doping because of reduced collection efficiency. 

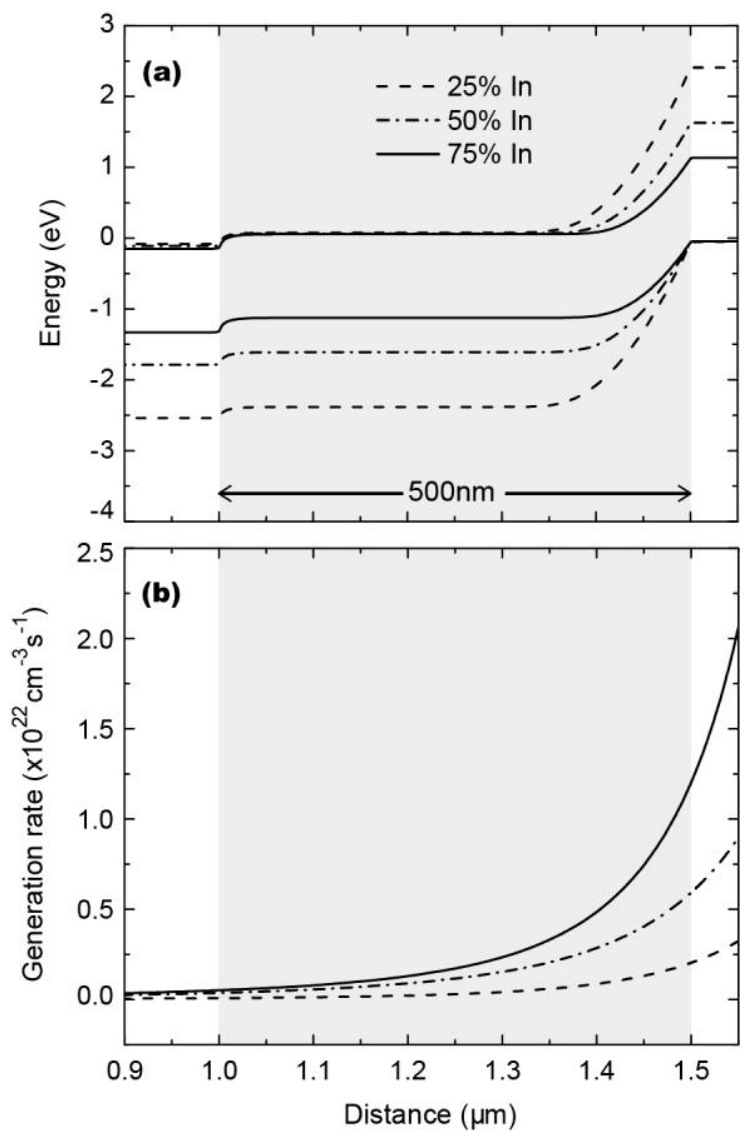

Fig. 24. (a) Band diagrams at equilibrium and (b) optical carrier generation rate under AM1.5 illumination for an $n-\operatorname{In}_{x} \mathrm{Ga}_{1-x} \mathrm{~N} / \mathrm{UID}-\mathrm{In}_{\mathrm{x}} \mathrm{Ga}_{1-\mathrm{x}} \mathrm{N} / \mathrm{p}-\mathrm{In}_{\mathrm{x}} \mathrm{Ga}_{1-\mathrm{x}} \mathrm{N}$ structure with various indium compositions. 


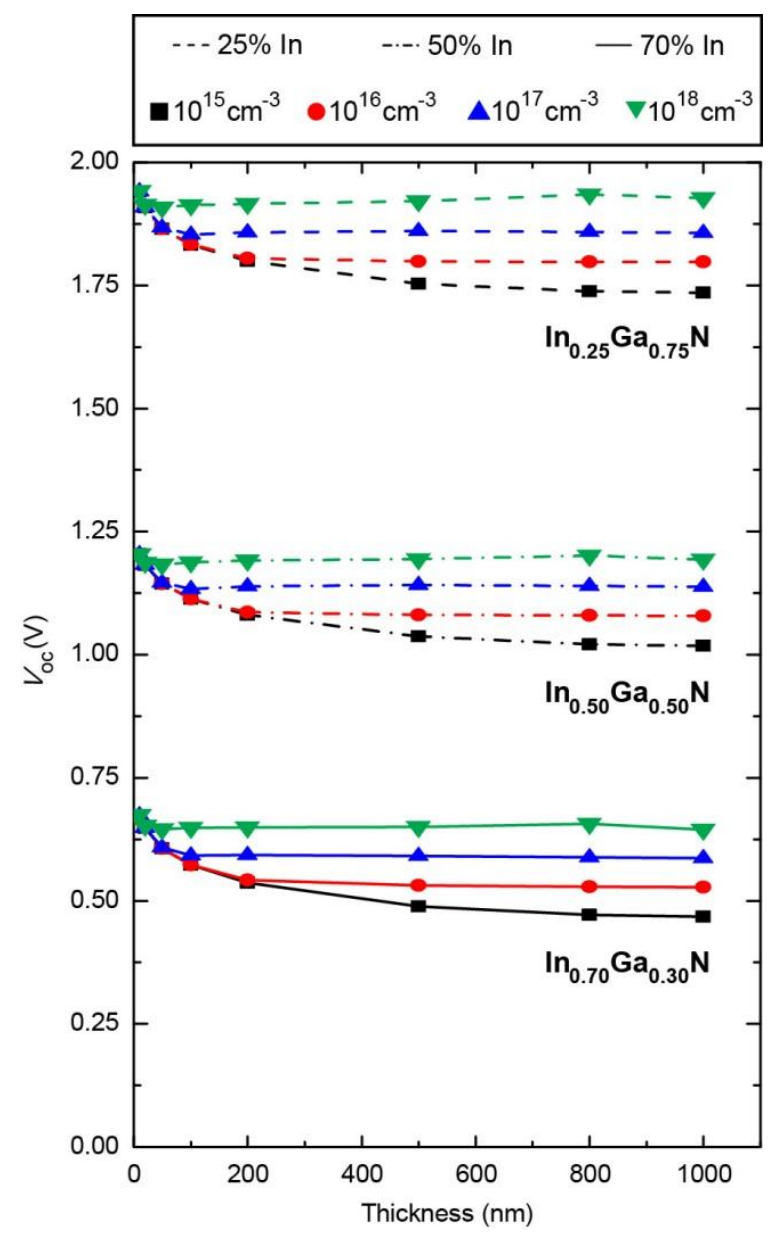

Fig. 25. Open-circuit voltage $V_{\text {oc }}$ as a function of UID-layer thickness for an $n-\operatorname{In}_{x} G a_{1-x} N / U I D-$ $\mathrm{In}_{\mathrm{x}} \mathrm{Ga}_{1-\mathrm{x}} \mathrm{N} / \mathrm{p}-\mathrm{In}_{\mathrm{x}} \mathrm{Ga}_{1-\mathrm{x}} \mathrm{N}$ solar cell with various indium compositions and concentrations of background donors. $V_{\text {oc }}$ decreases for cells with higher indium content due to reduced band gap, but increases for cells with higher background doping due to narrower depletion width. 

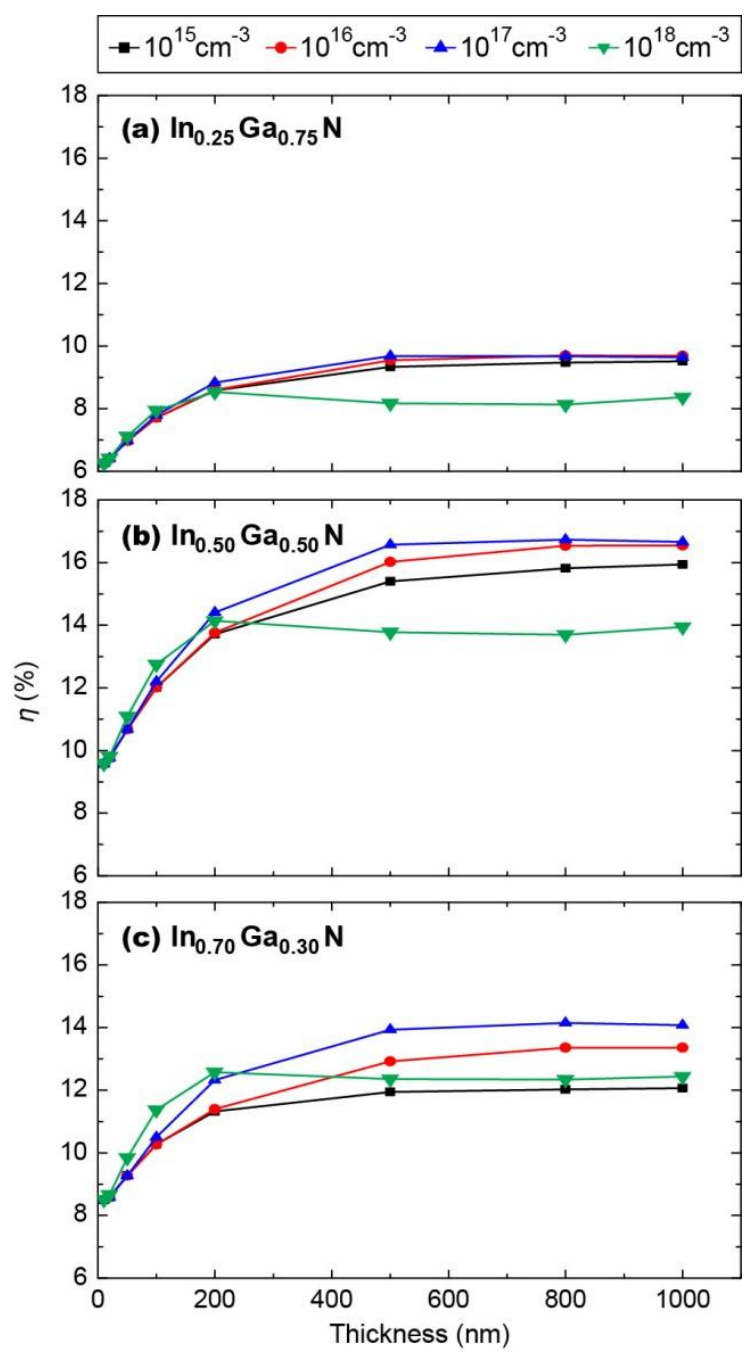

Fig. 26. Conversion efficiency $\eta$ as a function of UID-layer thickness for (a) $\operatorname{In}_{0.25} \mathrm{Ga}_{0.75} \mathrm{~N}$ (b) $\mathrm{In}_{0.50} \mathrm{Ga}_{0.50} \mathrm{~N}$ (c) $\mathrm{In}_{0.70} \mathrm{Ga}_{0.30} \mathrm{~N}$ p-i-n homojunction solar cells with various concentrations of background donors. The conversion efficiency accounts for the tradeoff between the opposite trends of $J_{\mathrm{sc}}$ and $V_{\mathrm{oc}}$. 


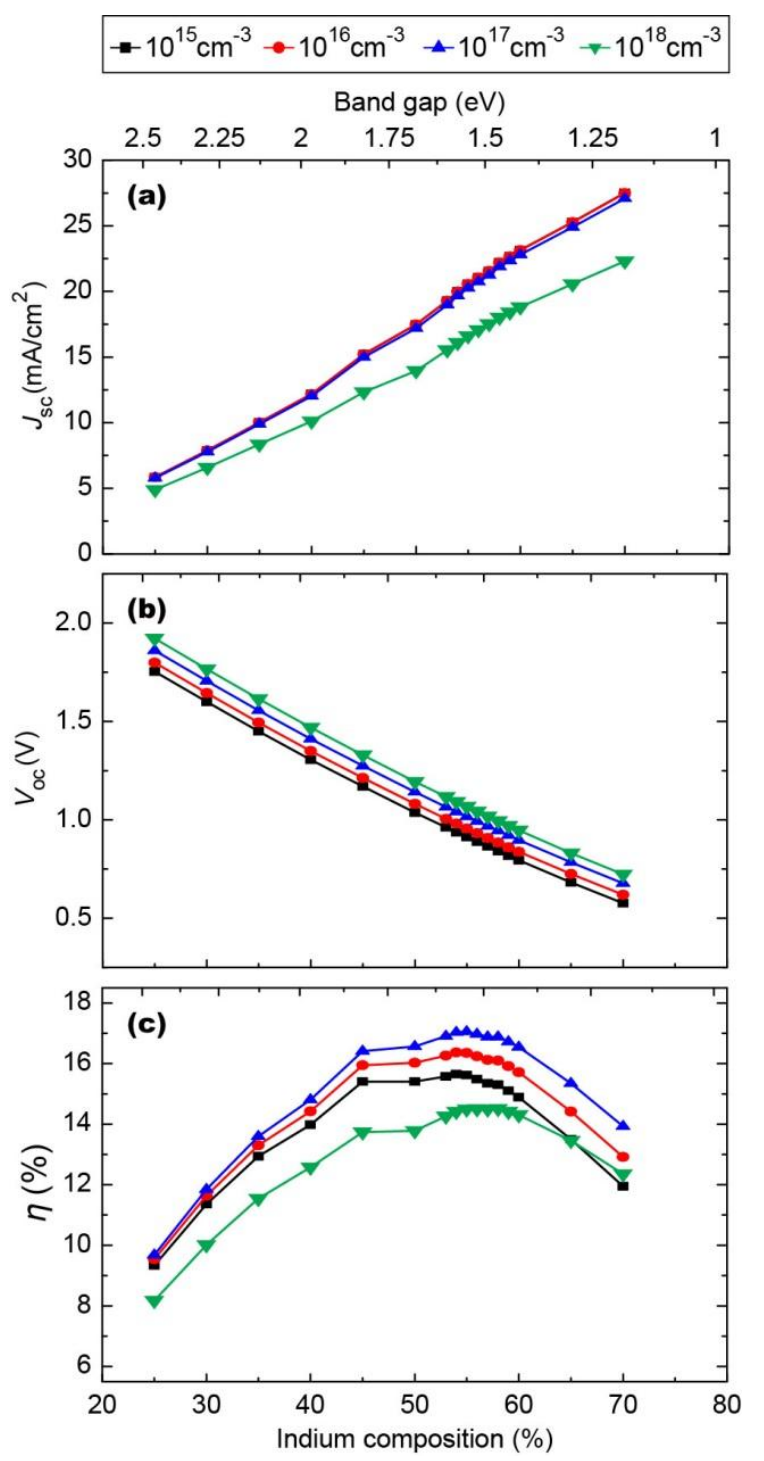

Fig. 27. (a) Short circuit current $J_{\mathrm{sc}}$, (b) open-circuit voltage $V_{\mathrm{oc}}$, and (c) conversion efficiency $\eta$ as a function of indium composition (i.e. band gap) for an $n-\operatorname{In}_{x} G_{1-x} N / U I D-\operatorname{In}_{x} G a_{1-x} N / p-\operatorname{In}_{x} G_{1-}$ ${ }_{x} \mathrm{~N}$ structure with various residual donor concentrations. The thickness of the UID-InGaN is 500 nm. 


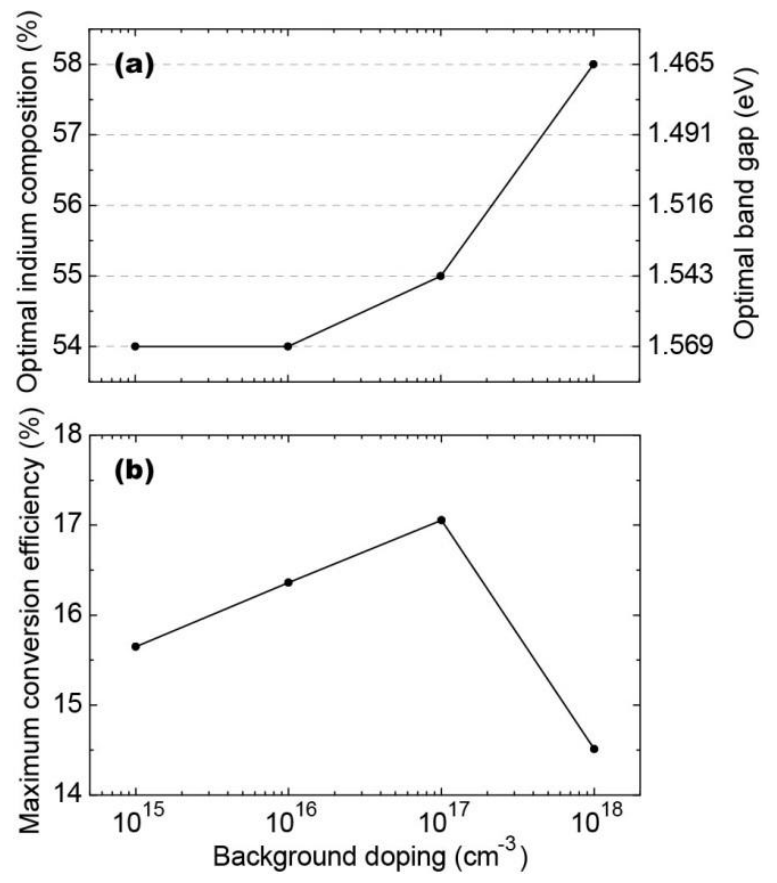

Fig. 28. Optimal indium composition and band gap as a function of background doping in the UID-InGaN layer for an $n-\operatorname{In}_{x} G_{1-x} N / U I D-\operatorname{In}_{x} G_{1-x} N / p-\operatorname{In}_{x} G_{1-x} N$ structure. As the background doping increases, the optimal band gap shifts to lower values. 